\title{
PERAN LPDB DAN KUMKM NATUNA UNTUK MENJADI POROS MARITIM INDONESIA
}

\author{
REZZY EKO CARAKA a \\ a College of Informatics, Chaoyang University of Technology, Jifeng East Road, Wufeng District, Taichung City, \\ 41349, Taiwan (ROC) \\ rezzyekocaraka@gmail.com / s10714905@gm.cyut.edu.tw
}

\section{INFO ARTIKEL}

\section{SEJARAH ARTIKEL}

Diterima Pertama

20 January 2019

Dinyatakan Dapat Dimuat 28 Juni 2019

\section{KATA KUNCI:}

LPDB

EKONOMI

MARITIM

PENDAPATAN DAERAH

KOMPONEN UTAMA

\section{ABSTRAK}

Penelitian ini dilatarbelakangi oleh kegiatan Ekspedisi Nusantara Jaya yang diikuti oleh Peneliti yang diselenggarakan oleh Kementerian Koordinator Bidang Kemaritiman Republik Indonesia di Natuna. Sumber daya alam yang melimpah di Natuna terutama Kekayaan laut dan perikanan yang kemudian ditargetkan oleh Pemerintah Indonesia sebagai poros maritim Indonesia sehingga perlu dilakukan analisis lebih mendalam. Tujuan penelitian ini adalah untuk mengetahui daerah mana saja yang memiliki kedekatan yang mirip dan akan mempermudah LPDB dalam melakukan pemetaan potensi daerah di Natuna. Penelitian ini melibatkan 3 variabel dependen yang terdiri dari laju PDRB, PBB, dan Jumlah Rumah Tangga Perikanan. Seterusnya melibatkan 12 variabel independen yang terdiri dari Pengeluaran Kapita, Indeks Kedalaman Kemiskinan, Jumlah Penduduk, Jumlah Usaha Mikro, Total Usaha, Jumlah Pedagang, Jumlah Koperasi, Produksi, Jumlah Rumah Tangga Perikanan Budidaya, Perahu Tanpa Motor, Perahu Motor Tempel, dan Kapal Motor. Semua tujuan analisis dapat dijawab dengan menggunakan biplot analisis komponen utama. Biplot adalah upaya membuat gambar di ruang berdimensi banyak menjadi gambar di ruang berdimensi dua. Pada Biplot pertama didapatkan 77.28 persen dari total keragaman data yang sebenarnya. Hal ini menunjukkan bahwa interpretasi biplot komponen utama yang dihasilkan mampu menerangkan dengan baik hubungan antara laju PDRB pada Kabupaten Natuna terhadap pengeluaran kapita dan Index kedalaman kemiskinan dan gini rasio di Natuna. Pada Biplot kedua didapatkan sebesar 82.17 persen dari total keragaman yang berarti mampu menerangkan 82.17 persen PBB Terhadap Jumlah Penduduk, Jumlah Usaha Mikro, Total Usaha, Jumah Pedagang, Jumlah Koperasi. Pada analisis ini juga didapatkan 4 dimensi daerah yang memiliki hubungan yang mirip sehingga mempermudah LPDB untuk memetakan potensi daerah di Natuna sebagai poros maritim Indonesia

This research was motivated by Nusantara Jaya Expedition activities which were followed by Researcher and organized by the Coordinating Ministry of Maritime Affairs of the Republic of Indonesia in Natuna. The abundant natural resources in Natuna are mainly marine wealth and fisheries, which are then targeted by the Indonesian government as Indonesia's maritime axis so that more in-depth analysis. The purpose of this study is to find out which areas have similar closeness and will make it easier for LPDB to map potential areas in Natuna. This study involved three dependent variables consisting of GRDP, UN, and Number of Fisheries Households. Then it meant 12 independent variables comprising Capita Expenditures, Poverty Index, Population, Micro Business Number, Total Business, Number of Traders, Number of Cooperatives, Production, Number of Aquaculture Households, Motorless Boats, Outboard Motorboats, and Motorboats. All analysis objectives can be answered using the principal component analysis biplot. Biplot is a method to make images in many dimensions of space into images in two-dimensional areas. The first Biplot obtained 77.28 percent of the total diversity of actual data. The interpretation of the main component of the biplot produced can explain very well the relationship between the rate of GDP in Natuna District to capita expenditure and the poverty depth index and the Gini ratio in Natuna. In the second Biplot obtain 82.17 percent of the total diversity, which means that it was able to explain 82.17 percent of the United Nations Against Population, Number of Micro Businesses, Total Businesses, Traders, Number of Cooperatives. In this analysis also found four dimensions of regions that have similar relationships, making it easier for LPDB to map the potential of the area in Natuna as Indonesia's maritime. 


\section{PENDAHULUAN}

\subsection{Latar Belakang}

Indonesia adalah salah satu negara yang memiliki potensi maritim yang besar. Indonesia terdiri dari sekelompok pulau dengan garis pantai yang mana panjangnya hingga $95.000 \mathrm{~km}$. Dengan keadaan geografis yang ada, Indonesia memiliki potensi besar untuk industri kelautan. Indonesia memiliki sektor ekonomi yang tidak bergantung pada daratan, tetapi juga di bidang kelautan dan membuat ekonomi berbasis kelautan terus tumbuh di Indonesia dan meningkatkan pengembangan industri lainnya. Industri bisnis yang terkait erat dengan transportasi laut adalah bisnis pelabuhan, transportasi multimodal, perusahaan asuransi, industri pembuatan kapal dan banyak lagi. Industri ini memiliki hubungan satu sama lain dan tumbuh bersama.

Salah satu industri yang berkembang seiring dengan perkembangan industri maritim adalah transportasi laut. Transportasi laut menjadi kekuatan utama bagi pengembangan industri maritim. Karena itu, Indonesia harus mengembangkan industri pembuatan kapal. Industri perkapalan memiliki prospek yang baik seiring dengan meningkatnya permintaan untuk transportasi massal dan logistik di tengah pertumbuhan ekonomi yang pesat di Indonesia. Dimana kapal sebagai alat transportasi yang menghubungkan kegiatan ekonomi antar pulau di Indonesia. Kapal penyedia transportasi dan fasilitas kerja pertambangan, perikanan, pariwisata, serta sistem pertahanan penyedia alat utama. Jadi kebutuhan kapal akan terus meningkat. Industri perkapalan memiliki prospek yang baik untuk mendukung kekuatan maritim Indonesia.

Galangan kapal sebagai tempat pembuatan produksi kapal di Indonesia masih terus berkembang untuk memenuhi kebutuhan pasar. Saat ini, Indonesia memiliki lebih dari 240 perusahaan galangan kapal. Berdasarkan World Shipbuilding Statistics pada 2007, peringkat Indonesia sebagai salah satu pembuat kapal dari 22 negara menempati peringkat dunia. Saat ini, jumlah industri pembuatan kapal di dalam negeri sebanyak 250 galangan kapal dengan kemampuan membangun 900.000 DWT baru / tahun dan kemampuan perbaikan 12.000.000 DWT / tahun. Itu artinya Indonesia memiliki kemampuan. Tingginya permintaan dari pasar lokal dan global membuat kinerja industri pelayaran nasional menunjukkan peningkatan.

Sebagai Negara kepulauan terbesar di dunia, Indonesia memiliki 16.056 pulau bernama yang didaftarkan ke PBB mulai dari Sabang hingga Merauke. Luas total wilayah Indonesia adalah 7,81 juta $\mathrm{km}^{2}$ yang terdiri dari 2,01 juta $\mathrm{km}^{2}$ daratan, 3,25 juta $\mathrm{km}^{2}$ lautan, dan 2,55 juta $\mathrm{km}^{2}$. Zona Ekonomi Eksklusif (ZEE) merupakan suatu Negara dengan luas perairan lebih besar dari pada luas daratan, maka dari itu Indonesia disebut sebagai Negara Maritim. Meningkatnya kebutuhan konsumsi perikanan di Indonesia dan juga mancanegara membuat peluang besar bagi daerah maritim untuk menjadi potensi bisnis yang akan mendapatkan pemasukan unit usaha di daerah tersebut. Potensi sumber daya pesisir dan laut di Indonesia begitu beragam baik dari segi kuantitas maupun kualitas, sehingga seharusnya memberikan kontribusi yang sangat penting terhadap pertumbuhan ekonomi Negara Indonesia. Sumber daya pesisir dan kelautan yang dimaksudkan secara garis besar dibagi kedalam tiga bagian, yaitu: sumber daya alam hayati, non hayati, energi dan mineral. Ketiga jenis sumber daya tersebut merupakan kekayaan alam yang potensial untuk dikembangkan dan dikelola sebagai sektor pembangunan andalan di masa yang akan datang.

Kekayaan laut yang dimiliki seperti ikan, udang, dan berbagai jenis hewan laut lainnya membuktikan bahwa Indonesia memiliki potensi yang luar biasa dalam sektor kelautan dan dapat menopang pendapatan asli daerah. Untuk mencapai pengelolaan yang efektif dan berkelanjutan, diperlukan identifikasi dan arahan pemanfaatan terhadap potensi sumber daya tersebut dan juga kemudahan untuk mendapatkan pinjaman dana untuk memulai bisnis.

Pendapatan Asli Daerah (PAD) adalah pendapatan yang diperoleh berdasarkan peraturan daerah sesuai dengan peraturan perundang-undangan untuk mengumpulkan dana bagi keperluan daerah yang bersangkutan dalam membiayai kegiatannya (BPS, 2013). Pendapatan Asli Daerah (PAD) memiliki peran yang cukup penting dalam menentukan kemampuan daerah untuk melakukan aktivitas pemerintahan dan program-program pembangunan. Pemerintah daerah diharapkan mampu meningkatkan PAD untuk mengurangi ketergantungan terhadap pembiayaan dari pusat, sehingga daerah bisa menunjukkan tingkat kemandiriannya. Sumber pendapatan daerah antara lain pajak daerah, retribusi daerah, hasil perusahaan milik daerah dan pengelolaan kekayaan daerah yang dipisahkan, lain-lain pendapatan asli daerah yang sah (BPS, 2013).

Penduduk yang tinggal di daerah pesisir umumnya bekerja atau bermata pencaharian sebagai nelayan. Nelayan sangat tergantung pada alam, tidak bisa setiap hari atau sepanjang tahun mereka dapat pergi melaut, karena tergantung dengan kondisi alam. Jika musim ombak besar otomatis para nelayan tidak ada yang pergi melaut, dan tidak akan melakukan penangkapan ikan sama sekali, mereka hanya berdiam sambil menunggu waktu yang baik untuk dapat melaut kembali. Selain pengaruh alam, sarana dan alat yang dipakai atau yang dimiliki oleh para nelayan sebagian besar masih sangat sederhana (Badan Pusat Statistik 2015).

Permasalahan yang sering muncul di desa terutama desa pesisir pada umumnya adalah kemiskinan dan pendidikan yang rendah. Kondisi tersebut dimanfaatkan oleh para tengkulak. Hampir di 
setiap wilayah pesisir di Indonesia dijumpai adanya tengkulak yang mengambil beberapa fungsi pengembangan di sektor perikanan dan kelautan secara informal. Dalam keadaan tidak melaut untuk memenuhi kebutuhan hidup sehari-hari banyak nelayan yang mengandalkan pada bantuan tengkulak/rentenir. Tidak hanya kebutuhan hidup sehari-hari saja, tetapi juga kebutuhan sekolah anakanaknya para nelayan menggantungkan pada pinjaman dari tengkulak. Para nelayan jarang yang memanfaatkan fasilitas bank dan lembaga keuangan lainnya menurut nelayan tradisional memerlukan persyaratan yang memberatkan mereka.

Sejalan dengan peningkatan ekspornya, produksi ikan Indonesia baik dari hasil penangkapan maupun budi daya juga terus mengalami peningkatan setiap tahunnya. Menurut Kementerian Kelautan dan Perikanan (KKP) produksi perikanan Indonesia telah meningkat mencapai 110 persen. Peningkatan yang sangat signifikan terjadi pada produksi perikanan budi daya yang meningkat lebih dari 3 kali lipat selama periode tersebut dengan peningkatan mencapai 208,28 persen. Sedangkan produksi perikanan tangkap selama periode tersebut secara total hanya meningkat sebesar 21,33 persen. Pertumbuhan produksi yang sangat cepat pada perikanan budi daya mengindikasikan adanya potensi yang besar dalam usaha pembudidayaan ikan sehingga usaha ini semakin diminati oleh masyarakat. Hal ini dibuktikan juga dengan jumlah rumah tangga usaha (RTU) perikanan budi daya yang meningkat dibandingkan RTU penangkapan ikan yang mengalami penurunan.

Pembangunan desa maritim merupakan suatu ide baru yang bertujuan untuk memberikan kesempatan bagi pengembangan dan kemajuan desa-desa di Indonesia, di wilayah pesisir/daerah pantai. Dan bila kita inginkan agar Indonesia menjadi Pusat kemaritiman di Asia Tenggara, maka pembangunan yang dilaksanakan pemerintah bukan hanya berfokus pada area pesisir/pantai tapi juga harus berorientasi kepada pesisir, laut serta daratan karena saling memiliki keterkaitan satu dengan yang lain. Pembangunan desa maritim sendiri dapat terlaksana ketika adanya pemenuhan faktor-faktor pendukung terlaksananya pembangunan desa maritim. Misalnya
a. transportasi yang memadai
b. adanya sumber daya manusia berkualitas
c. adanya fokus pembangunan yang dimulai dari desa ke kota, dan bukan kota barulah ke desa

yang

Pemberdayaan dan peningkatan infrastruktur merupakan alat utama dalam pembangunan masyarakat pesisir. Masyarakat pesisir yang masuk dalam kategori tertinggal perlu penanganan serius dari pemerintah. Dibutuhkan sebuah program pembangunan yang best practice sebagai upaya pembangunan berkelanjutan. Begitu pula pembangunan yang tepat guna dan tepat sasaran menjadi kunci awal yang perlu dilakukan dan dikembangkan sebagai upaya peningkatan ekonomi dan kesejahteraan bagi masyarakat pesisir.

Usaha Mikro, Kecil dan Menengah (UMKM) adalah merupakan punggung ekonomi Indonesia. Hingga kini, jumlah UMKM di Indonesia mencapai kurang lebih sekitar 56, 5 juta unit. UMKM di Indonesia memiliki peranan penting bagi perekonomian di Indonesia, hal ini dikarenakan UMKM menyumbang $60 \%$ dari PDB dan menampung 97\% tenaga kerja. Maka dari itu, bila tidak diperhatikan dengan serius maka pertumbuhan ekonomi nasional akan rapuh (Firdamansyah 2017). Natuna memiliki potensi perekonomian yang besar dan berpotensi menjadi pusat konsentrasi maritim dan pusat pengembangan Indonesia bagian barat di masa mendatang.

Berdasarkan Undang- Undang Nomor 20 Tahun 2008 tentang Usaha Mikro, Kecil dan Menengah (UMKM) pengertian UMKM adalah sebagai berikut (Departemen Koperasi Indonesia. 2008):

1. Usaha Mikro adalah usaha produktif milik orang perorangan dan/atau badan usaha perorangan yang memenuhi kriteria Usaha Mikro sebagaimana diatur dalam UndangUndang ini.

2. Usaha Kecil adalah usaha ekonomi produktif yang berdiri sendiri, yang dilakukan oleh orang perorangan atau badan usaha yang bukan merupakan anak perusahaan atau bukan cabang perusahaan yang dimiliki, dikuasai, atau menjadi bagian baik langsung maupun tidak langsung dari usaha menengah atau usaha besar yang memenuhi kriteria Usaha Kecil sebagaimana dimaksud dalam Undang-Undang ini.

3. Usaha Menengah adalah usaha ekonomi produktif yang berdiri sendiri, yang dilakukan oleh orang perseorangan atau badan usaha yang bukan merupakan anak perusahaan atau cabang perusahaan yang dimiliki, dikuasai, atau menjadi bagian baik langsung maupun tidak langsung dengan usaha kecil atau usaha besar dengan jumlah kekayaan bersih atau hasil penjualan tahunan sebagaimana diatur dalam Undang Undang ini.

Berikut adalah kriteria UMKM berdasarkan UndangUndang Nomor 20 Tahun 2008 tentang Usaha Mikro, Kecil dan Menengah (UMKM)

Tabel 1. Kriteria UMKM

\begin{tabular}{|l|l|l|}
\hline Uraian & Aset & Omzet \\
\hline Usaha Mikro & Max 50 Juta & Max 300 Juta \\
\hline Usaha Kecil & $\begin{array}{l}>50 \text { Juta }-500 \\
\text { Juta }\end{array}$ & $\begin{array}{l}>300 \text { juta }-2.5 \\
\text { Miliar }\end{array}$ \\
\hline $\begin{array}{l}\text { Usaha } \\
\text { Menengah }\end{array}$ & $\begin{array}{l}>500 \text { juta }-10 \\
\text { Miliar }\end{array}$ & $>2.5-50$ Miliar \\
\hline
\end{tabular}


Berdasarkan Tabel 1 dapat disimpulkan bahwa usaha yang tergolong UMKM memiliki omzet dengan rentang 0 - 50 Miliar Rupiah dan memiliki nilai aset dengan rentang 0 - 10 Miliar Rupiah.

Triyono dan Romadona (2018) mengkaji produk unggulan perikanan di Kabupaten Natuna diawali melalui penjajakan potensi sumber daya yang ada dengan mempertimbangkan sektor unggulan daerah. Pada tahapan ini diperoleh informasi bahwa sektor unggulan di Kabupaten Natuna adalah pertanian, kehutanan dan perikanan.

Melalui proses FGD dan mempertimbangkan statistik potensi daerah, diperoleh 3 produk yang nantinya akan ditetapkan sebagai Produk Unggulan Perikanan. Produk tersebut antara lain; Kerupuk Ikan/ Kerupuk atom; Kernas/Kasam ; Ikan Salai. Analisis FGD yang menghasilkan 3 produk unggulan selanjutnya ditentukan prioritas pengembangan melalui analisis daya tarik dan daya saing. Dalam analisis ini, daya tarik dan daya saing dibagi dalam beberapa faktor dengan kriteria mempertimbangkan Permendagri No.9 Tahun 2014 untuk kem udian diberi nilai secara kuantitatif. Hasil analisis berdasarkan prioritas pengem bangan yaitu: (1). Kerupuk Ikan, (2). Ikan Salai, (3) Kernas/Kasang.

Pigawati (2005) mengkaji dan mengidentifikasi potensi sumber daya pesisir dan pulau-pulau kecil meliputi sebaran dan kualitasnya serta memberikan arahan lokasi penambangan pasir laut di Kabupaten Natuna berdasarkan pertimbangan keberadaan kawasan konservasi. Didapatkan bahwa Kecamatan Bunguran Barat merupakan kawasan potensial sumber daya terumbu karang, klorofil dan sedimen/ pasir laut, sedangkan potensi padang lamun dan mangrove berada pada Kecamatan Bunguran Timur. Dalam melakukan sumber daya pesisir dan pulau-pulau kecil perlu diberikan arahan kawasan yang boleh di eksplorasi dengan mempertimbangkan keberadaan kawasan konservasi dalam rangka mewujudkan pembangunan berkelanjutan yang berwawasan lingkungan.

Program pemerintah yang memiliki tujuan untuk menekan angka kemiskinan dan meningkatkan potensi usaha pada daerah, antara lain yang popular di penggiat usaha di Natuna adalah PEMP (Pemberdayaan Ekonomi Masyarakat Pesisir) yang dilaksanakan Kementerian Kelautan Perikanan. Dalam kenyataannya, banyak pelaku KUMKM di Natuna memiliki keterbatasan kemampuan dalam mengakses pinjaman/pembiayaan dari perbankan. Hal tersebut menyebabkan potensi usaha yang memiliki prospek bagus kehilangan kesempatan memaksimalkan peluang usaha yang tersedia terutama untuk menuju Natuna sebagai poros maritim Indonesia. Untuk meningkatkan akses pembiayaan usaha bagi Koperasi dan UMKM, sekaligus meningkatkan pelayanan pemerintah kepada masyarakat dalam rangka memajukan sektor usaha produktif, peningkatan lapangan usaha dan lapangan kerja, Kementerian
Koperasi dan UKM membentuk badan layanan umum yaitu Lembaga Pengelola Dana Bergulir KUMKM (LPDB-KUMKM).

Lembaga Pengelola Dana Bergulir Koperasi dan Usaha Mikro, Kecil dan Menengah (LPDB-KUMKM) merupakan Satuan Kerja dari Kementerian Koperasi dan UKM yang menerapkan pola pengelolaan Badan Layanan Umum (BLU) (LPDB 2017). Ketentuan tentang BLU diatur dalam beberapa peraturan, terakhir dalam Peraturan Pemerintah Nomor 74 Tahun 2012 tentang Perubahan Atas Peraturan Pemerintah Nomor 23 Tahun 2005 Tentang Pengelolaan Keuangan Badan Layanan Umum.

Hingga saat ini telah ada 203 satuan kerja yang menerapkan pola Pengelolaan Keuangan Badan Layanan Umum (PK-BLU). PK BLU ini berada dalam pembinaan Direktorat Pembinaan Pengelolaan Keuangan Badan Layanan Umum Kementerian Keuangan. LPDB-KUMKM termasuk salah satu BLU yang memiliki status penuh berdasarkan KEP292/MK.5/2006 tanggal 28 Desember 2006 tentang Penetapan Lembaga Pengelola Dana Bergulir Koperasi dan Usaha Mikro, Kecil dan Menengah pada Kementerian Negara Koperasi dan Usaha Kecil dan Menengah Sebagai Instansi Pemerintah yang Menerapkan Pola Pengelolaan Keuangan Badan Layanan Umum (PPK-BLU).LPDB-KUMKM memiliki tugas pokok dalam pengelolaan dana bergulir, antara lain :

a. Melaksanakan penghimpunan, pengalihan dan pengembalian dana bergulir dari pinjaman program dana bergulir Kementerian Koperasi dan UKM, dan penyalur pinjaman/ pembiayaan yang telah dilaksanakan LPDBKUMKM;

b. Melaksanakan pemberian pinjaman /pembiayaan kepada Koperasi, Usaha Mikro, Kecil dan Menengah (KUMKM), dengan atau tanpa lembaga perantara, baik Lembaga Keuangan Bank (LKB), maupun Lembaga Keuangan Bukan Bank (LKBB)

c. Melaksanakan pemberian bentuk pembiayaan lainnya bagi KUMKM sesuai dengan kebutuhan KUMKM.

Perbedaan penelitian ini dengan penelitian sebelumnya adalah melibatkan spasial dari masingmasing lokasi di Natuna dan juga variabel yang akan dianalisis lebih lanjut, untuk mendapatkan informasi lokasi mana yang perlu perhatian khusus oleh LPDB. Bentuk pembiayaan dan kriteria diatur oleh LPDB yang bermanfaat untuk pegiat bisnis di wilayah Natuna dan dapat membantu untuk mewujudkan Natuna sebagai poros maritim Indonesia. 


\subsection{Perumusan Masalah}

Berdasarkan uraian latar belakang tersebut, masalah yang akan dibahas dalam penulisan ini adalah potensi Natuna sebagai poros maritim Indonesia dengan menggunakan analisis biplot komponen utama.

1. Menganalisis informasi dan keragaman masing-masing variabel yang dianggap dapat mewakili informasi untuk menyiapkan Natuna sebagai poros maritim Indonesia

2. Mengetahui daerah yang memiliki kemiripan karakteristik dengan daerah lain.

3. Menyajikan posisi relatif suatu daerah terhadap potensi yang dimiliki dan korelasi variabel-variabelnya serta menentukan bagaimana peran Lembaga Pengelola Dana Bergulir (LPDB).

\subsection{Ruang Lingkup Penelitian}

Penelitian ini merupakan jenis penelitian kuantitatif yang melibatkan 3 variabel dependen utama yaitu Laju PDRB $\left(Y_{1}\right)$, Pajak Bumi dan Bangunan $\left(Y_{2}\right)$ dan Jumlah Rumah Rangga Perikanan $\left(Y_{3}\right)$. Penelitian ini untuk mendapatkan variabel mana yang memiliki hubungan kekerabatan paling dekat dan akan terdapat 3 analisis utama yaitu : Laju PDRB terhadap Pengeluaran Kapita, dan Index Kedalaman Kemiskinan, PBB terhadap Jumlah Penduduk di setiap wilayah di Natuna, Jumlah usaha mikro, total usaha, jumah pedagang, jumlah koperasi. Jumlah Rumah Tangga Perikanan (Marine Fisheries), Produksi (Production), Jumlah Rumah Tangga Perikanan Budidaya (Aquaculture Fishery Households), Perahu tanpa motor (nonpowered boat), Perahu motor tempel (outboard motorboat), dan kapal motor (inboard motorboat).

\section{KERANGKA TEORITIS DAN PENGEMBANGAN HIPOTESIS.}

\subsection{Profil Natuna}

Secara administratif Kabupaten Natuna termasuk dalam wilayah Provinsi Kepulauan Riau. Kabupaten ini baru dibentuk pada tahun 1999 sebagai hasil pemekaran Kabupaten Kepulauan Riau berdasar pada UU No. 53 Tahun 1999, yang menyebutkan Kabupaten Kepulauan Riau (Kabupaten Bintan), Kabupaten Karimun, dan Kabupaten Natuna sebagai daerah otonom. Menurut data yang diperolehdari pemerintah daerah terdapat 154 pulau di Kabupaten ini, dengan 27 pulau (17,53 persen) yang berpenghuni dan127 pulau $(82,44$ persen) tidak berpenghuni. Dari semua kecamatan, Kecamatan Serasan memiliki jumlah pulau terbanyak yang belum berpenghuni yaitu 30 pulau (23,62 persen dari total pulau belum berpenghuni) (Badan Pusat Statistik 2018).

\subsection{Masyarakat Maritim}

Negara Maritim adalah negara yang berdaulat, menguasai, mampu mengelola dan memanfaatkan secara berkelanjutan dan memperoleh kemakmuran dari laut. Dengan demikian apabila membicarakan negara maka digunakan istilah Negara Maritim karena terkait dengan kata sifat yakni mengelola dan memanfaatkan laut untuk kejayaan negaranya (Subagyo et al. 2017). Masyarakat maritim adalah kelompok masyarakat yang kehidupan dan perekonomian dominan pada potensi sumber daya laut dan juga perikanan. Masyarakat maritim dapat sebagai pembudidaya ikan, pengolah ikan, pedagang ikan, penambangan pasir dan transportasi laut.

\subsection{Pendapatan Asli Daerah}

Pendapatan asli daerah merupakan pendapatan daerah yang bersumber dari hasil pajak daerah, hasil retribusi daerah, hasil pengelolaan kekayaan daerah yang dipisahkan, dan pendapatan lain asli daerah yang sah, yang bertujuan untuk memberikan keleluasaan kepada daerah dalam menggali pendanaan, dalam pelaksanaan otonomi daerah sebagai perwujudan asas desentralisasi. Pendapatan asli daerah masyarakat maritim lebih banyak terdapat pada usaha yang di bidang perikanan dan juga transportasi laut Berdasarkan Undang-Undang No. 22 Tahun 1999 disebutkan bahwa sumber pendapatan asli daerah terdiri dari pajak daerah, retribusi daerah, hasil perusahaan milik daerah dan pengelolaan kekayaan daerah yang dipisahkan, lain-lain pendapatan asli daerah yang sah. Menurut Santoso dan Rahayu (2005) faktor-faktor yang mempengaruhi pendapatan asli daerah (PAD) antara lain pengeluaran pemerintah, Produk Domestik Regional Bruto (PDRB) dan jumlah penduduk.

Berdasarkan sumber-sumber dan faktor-faktor di atas maka dalam penelitian ini digunakan variabelvariabel sebagai berikut:

1. Pajak daerah merupakan iuran wajib yang dilakukan oleh orang pribadi atau badan kepala daerah tanpa imbalan langsung yang seimbang, yang dapat dipaksakan berdasarkan peraturan perundang-undangan yang berlaku, yang digunakan untuk membiayai penyelenggaraan pemerintahan daerah dan pembangunan daerah (Yani, 2009). Berdasarkan Undang-Undang No. 34 Tahun 2000 tentang perubahan atas UndangUndang No. 18 Tahun 1997 tentang pajak dan retribusi daerah, pajak dirinci menjadi (Mardiasmo, 2002):

a. Pajak provinsi terdiri atas pajak kendaraan bermotor dan kendaraan di atas air, bea balik nama kendaraan bermotor (BBNKB) dan kendaraan di atas air, pajak bahan bakar kendaraan bermotor, dan pajak pengambilan dan pemanfaatan air bawah tanah dan air permukaan.

b. Jenis pajak kabupaten atau kota terdiri atas pajak hotel, pajak restoran, pajak hiburan, pajak reklame, pajak penerangan jalan, pajak pengambilan bahan galian golongan $\mathrm{C}$ dan pajak parkir. 
Karena pajak daerah merupakan salah satu sumber PAD maka dengan meningkatnya pajak daerah maka PAD juga akan meningkat.

2. Retribusi daerah merupakan pungutan daerah sebagai pembayaran atas jasa atau pemberian izin tertentu yang khusus disediakan atau diberikan oleh Pemerintah Daerah untuk kepentingan orang pribadi atau badan (BPS, 2013). Berdasarkan Undang-Undang No. 34 Tahun 2000 tentang perubahan atas Undang-Undang No. 18 Tahun 1997 tentang Pajak dan Retribusi Daerah, retribusi dirinci menjadi retribusi jasa umum, retribusi jasa usaha, retribusi perijinan tertentu (Mardiasmo, 2002). Karena retribusi daerah merupakan salah satu sumber PAD maka dengan meningkatnya retribusi daerah maka PAD juga akan meningkat.

3. PDRB atas dasar harga berlaku, perkembangan PDRB atas dasar harga berlaku dari tahun ke tahun menggambarkan perkembangan yang disebabkan oleh adanya perubahan dalam volume produksi barang dan jasa yang dihasilkan dan perubahan dalam tingkat harganya. PDRB atas dasar harga berlaku dapat dihitung dengan menggunakan dua metode yaitu metode langsung dan metode tidak langsung (BPS 2015). Dengan meningkatnya PDRB atas dasar harga berlaku maka akan menambah penerimaan pemerintah daerah untuk membiayai program-program pembangunan.

4. PDRB atas dasar harga konstan, perhitungan atas dasar harga konstan ini berguna antara lain dalam perencanaan ekonomi, proyeksi dan untuk menilai pertumbuhan ekonomi secara keseluruhan maupun sektoral. Nilai atas dasar harga konstan juga mencerminkan kuantum produksi pada tahun yang berjalan yang dinilai atas dasar harga pada tahun dasar (BPS 2015). Dengan meningkatnya PDRB atas dasar harga konstan maka akan menambah penerimaan pemerintah daerah untuk membiayai program-program pembangunan.

5. Penduduk adalah semua orang yang berdomisili di wilayah geografis Republik Indonesia selama 6 bulan atau lebih dan atau mereka yang berdomisili kurang dari 6 bulan tetapi bertujuan untuk menetap. Dengan didukung bukti empiris bahwa pertumbuhan penduduk tinggi akan dapat menaikkan output melalui penambahan tingkat dan ekspansi pasar baik pasar dalam negeri maupun luar negeri. Penambahan penduduk tinggi yang diiringi dengan perubahan teknologi akan mendorong tabungan dan juga penggunaan skala ekonomi di dalam produksi. Penambahan penduduk merupakan satu hal yang dibutuhkan dan bukan suatu masalah, melainkan sebagai unsur penting yang dapat memacu pembangunan dan pertumbuhan ekonomi. Jika jumlah penduduk meningkat maka pendapatannya juga bisa meningkat.
6. Belanja daerah adalah semua kewajiban daerah yang diakui sebagai pengurang nilai kekayaan bersih dalam periode tahun anggaran yang bersangkutan. Belanja daerah terdiri dari belanja tidak langsung dan belanja langsung. Belanja tidak langsung adalah bagian belanja yang dianggarkan tidak terkait langsung dengan pelaksanaan program sedangkan belanja langsung adalah bagian belanja yang dianggarkan terkait langsung dengan pelaksanaan program (BPS 2015). Peran pemerintah dalam pembangunan membutuhkan berbagai sarana dan fasilitas pendukung, termasuk anggaran belanja dalam rangka terlaksananya pembangunan yang berkesinambungan. Perbelanjaan-belanjaan tersebut akan meningkatkan pengeluaran agregat dan mempertinggi tingkat kegiatan ekonomi. Dengan meningkatnya kegiatan ekonomi, maka aliran penerimaan pemerintah melalui PAD juga akan meningkat.

\subsection{Analisis Komponen Utama}

Analisis Biplot Komponen Utama atau juga disebut dengan biplot klasik (Greenacre 2009) adalah salah satu teknik statistika deskriptif berupa representasi grafik yang dapat menyajikan secara simultan $n$ buah objek dan $p$ buah variabel dalam satu grafik berdimensi dua (Streiner 1993).

Analisis biplot adalah gambaran grafik dan matriks nxp dan mengacu pada dua jenis informasi yang terkandung dalam data matriks. Informasi dalam baris berkaitan dengan smpel atau unit sampling dan kolom berkaitan dengan variable (Beh 2012).

Proses analisis biplot memerlukan data dari sejumlah objek dengan atribut-atribut (kolom dari matriks data $X$ ), yang diukur dengan skala interval dan rasio (Pieter $M$ 2017). Hasil akhir analisis ini akan diberikan dalam bentuk tampilan gambar dua dimensi yang berisi informasi tentang :

A. Posisi relatif objek. Berdasarkan informasi ini dua objek yang memiliki jarak terdekat dikatakan memiliki tingkat kemiripan yang tinggi berdasarkan atribut-atribut yang diamati.

B. Hubungan antar atribut, dari informasi ini akan diketahui mengenai hubungan linier (korelasi) antar atribut serta tingkat kepentingan suatu atribut yang didasarkan pada variannya.

C. Penggabungan informasi (1) dan (2) dikenal dengan istilah bi-plot, akan diketahui ciri-ciri masing-masing objek berdasarkan atribut yang diamati. Analisis biplot menggabungkan antara plot variabel asal

Dengan plot pengamatan melalui superimpose akan memberi informasi tentang hubungan antara variabel dengan pengamatan (Gower, Lubbe, and Roux 2011). 
Dengan penyajian seperti ini, ciri -ciri variabel dan objek pengamatan serta posisi relatif antara objek pengamatan dengan variabel dapat dianalisis (Pieter M 2017). Analisis Biplot pertama kali diperkenalkan oleh (Bradu and Gabriel 1978). Empat hal penting yang bisa didapatkan dari tampilan biplot adalah:

A. Kedekatan antar objek yang diamati

Informasi ini dapat dijadikan panduan untuk mengetahui objek yang memiliki kemiripan karakteristik dengan objek lain. Penafsiran ini mungkin akan berbeda untuk setiap bidang terapan, namun inti dari penafsiran ini adalah bahwa dua objek yang memiliki karakteristik sama akan digambarkan sebagai dua titik dengan posisi yang berdekatan.

\section{B. Keragaman variabel}

Informasi ini digunakan untuk melihat apakah ada variabel yang mempunyai nilai keragaman yang hampir sama untuk setiap objek. Dengan informasi ini, bisa diperkirakan pada variabel mana strategi tertentu harus ditingkatkan, dan juga sebaliknya.

\section{Korelasi antar variabel}

Dari informasi ini bisa diketahui bagaimana suatu variabel mempengaruhi ataupun dipengaruhi variabel yang lain.

\section{Nilai variabel pada suatu objek}

Informasi ini digunakan untuk melihat keunggulan dari setiap objek. Objek yang terletak searah dengan arah vektor variabel dikatakan bahwa objek tersebut mempunyai nilai di atas rata-rata.

Perlu dipahami sebelumnya bahwa biplot adalah upaya membuat gambar di ruang berdimensi banyak menjadi gambar di ruang berdimensi dua. Pereduksian dimensi ini mengakibatkan menurunnya informasi yang terkandung dalam biplot. Biplot yang mampu memberikan informasi sebesar $70 \%$ dari seluruh informasi dianggap cukup (Greenacre 2009).

Analisis komponen utama digunakan untuk menemukan suatu kombinasi linier dari kovarian yang saling tidak berkorelasi satu dengan yang lain, sehingga masalah multikolinieritas dapat dihindari. Selain itu analisis komponen utama dapat memastikan bahwa kombinasi linier yang dipilih memiliki varian maksimal. Komponen utama merupakan kombinasi linear dari variabel random $\mathrm{k}\left(\mathrm{X}_{1}, \mathrm{X}_{2}, \ldots ., \mathrm{X}_{\mathrm{k}}\right)$. Analisis komponen utama tergantung pada matriks kovarian $\Sigma$ atau matriks korelasi $\boldsymbol{\rho}$. Misalkan vektor random $\mathbf{X}^{\prime}=$ $\left[\mathrm{X}_{1}, \mathrm{X}_{2}, \ldots, \mathrm{X}_{\mathrm{k}}\right]$ mempunyai matriks kovarian $\boldsymbol{\Sigma}$ dengan nilai eigen $\lambda_{1} \geq \lambda_{2} \geq \cdots \geq \lambda_{k} \geq 0$ maka bentuk kombinasi linier sebagai berikut:

$$
\begin{gathered}
W_{1}=\mathbf{a}_{1}{ }^{\prime} \mathbf{X}=\mathrm{a}_{11} \mathrm{X}_{1}+\mathrm{a}_{12} \mathrm{X}_{2}+\cdots+\mathrm{a}_{1 \mathrm{k}} \mathrm{X}_{\mathrm{k}} \\
\mathrm{W}_{2}=\mathbf{a}_{2}{ }^{\prime} \mathbf{X}=\mathrm{a}_{21} \mathrm{X}_{1}+\mathrm{a}_{22} \mathrm{X}_{2}+\cdots+\mathrm{a}_{2 \mathrm{k}} \mathrm{X}_{\mathrm{k}} \\
\vdots \\
\mathrm{W}_{\mathrm{k}}=\mathbf{a}_{\mathrm{k}}{ }^{\prime} \mathbf{X}=\mathrm{a}_{\mathrm{k} 1} \mathrm{X}_{1}+\mathrm{a}_{\mathrm{k} 2} \mathrm{X}_{2}+\cdots+\mathrm{a}_{\mathrm{kk}} \mathrm{X}_{\mathrm{k}}
\end{gathered}
$$

$$
\begin{array}{ll}
\operatorname{Cov}\left(\mathrm{W}_{\mathrm{j}}, \mathrm{W}_{\mathrm{l}}\right)=\mathbf{a}_{\mathrm{j}}{ }^{\prime} \boldsymbol{\sum} \mathbf{a}_{\mathrm{l}} & \mathrm{j}, \mathrm{l}=1,2, \ldots, \mathrm{k} \\
\operatorname{Var}\left(\mathrm{W}_{\mathrm{j}}\right)=\mathbf{a}_{\mathrm{j}}{ }^{\prime} \boldsymbol{\sum} \mathbf{a}_{\mathrm{j}} & \mathrm{j}=1,2, \ldots, \mathrm{k}
\end{array}
$$

Jumlah komponen utama dapat ditentukan dengan melihat persentase total varian ketika $\mathrm{j}(\mathrm{j}<\mathrm{k})$ buah komponen yang dipilih mampu menerangkan varian sekitar 80\% sampai 90\%. Komponen yang diambil tersebut sudah dapat menggantikan variabel $\mathrm{k}$ aslinya tanpa banyak kehilangan informasi.

Jumlah komponen utama juga dapat diketahui dengan menggunakan scree plot. Scree plot adalah plot antara $\lambda_{j}$ dengan $j$, besarnya nilai eigen. Untuk menentukan jumlah komponen utama dengan melihat tikungan tajam pada scree plot. Jumlah komponen yang diambil adalah yang nilai eigen relatif kecil dan semua berukuran sama. Estimator bias dari Koefisien regresi dapat diperoleh dengan menggunakan prosedur yang dikenal dengan regresi komponen utama. Berdasarkan bentuk persamaan resmi dari model yaitu:

$$
\mathbf{y}=\mathbf{Q} \alpha+\varepsilon
$$

dimana $\mathbf{Q}=\mathbf{X T}, \quad \alpha=\mathbf{T}^{\prime} \boldsymbol{\beta}, \quad \mathbf{T}^{\prime} \mathbf{X}^{\prime} \mathbf{X} \mathbf{T}=\mathbf{Q}^{\prime} \mathbf{Q}=\boldsymbol{\Lambda}$

$$
\begin{aligned}
& \boldsymbol{\Lambda}=\operatorname{diag}\left(\lambda_{1}, \lambda_{2}, \ldots, \lambda_{\mathrm{k}}\right) \text { adalah matriks diagonal } \\
& \text { dari nilai eigen } \mathbf{X}^{\prime} \mathbf{X} \\
& \mathbf{T} \text { adalah matriks orthogonal } \mathrm{k} \mathrm{X} \mathrm{k} \text { yang } \\
& \text { memiliki vektor eigen yang berhubungan } \\
& \text { dengan } \lambda_{1}, \lambda_{2}, \ldots, \lambda_{\mathrm{k}} .
\end{aligned}
$$

Pada bagian ini dapat dihitung koordinat dari bagian principal component plots. $\mathrm{Y}=\mathrm{XA}^{\prime}$, representasi dua dimensi $c 22$ dari $\boldsymbol{Y}_{C}$ berdasarkan komponen utama (yang merupakan representasi yang sama seperti yang didasarkan pada dekomposisi nilai tunggal).

$$
\boldsymbol{Y}_{c \cong} X_{2} A_{2}^{\prime}=\left(\begin{array}{cc}
x_{11} & x_{2} \\
\vdots & \vdots \\
x_{n 1} & x_{n 2}
\end{array}\right)\left(\begin{array}{ccc}
a_{11} & \cdots & a_{p 1} \\
a_{12} & \cdots & a_{p 2}
\end{array}\right)
$$

Oleh karena itu, diplotkan titik $\left(x_{i 1}, x_{12}\right) i=1,2, \ldots, n i$ dan titik $\left(a_{j 1}, a_{j 2}\right) j=1,2, \ldots, p$. Untuk membedakan individu dan variabel, titik $\left(a_{j 1}, a_{j 2}\right)$ dihubungkan dengan titik origin $(0,0)$ oleh garis lurus membentuk sebuah panah (R.E. Caraka and Yasin 2018). Jika diperlukan, skala dari titik $\left(a_{j 1}, a_{j 2}\right)$ menyesuaikan menjadi sama dengan komponen utama $\left(x_{i 1}, x_{12}\right)$. Cosinus dari sudut antara tanda panah (garis) digambarkan untuk setiap sepasang dari sumbu titik $\left(a_{j 1}, a_{j 2}\right)$ dan $\left(a_{k 1}, a_{k 2}\right)$ menunjukkan korelasi antara dua variabel yang sesuai (R.E. Caraka and Tahmid 2019).

Jadi sebuah sudut kecil antara dua vektor menunjukkan dua variabel atau lebih berkorelasi, dua variabel yang vektornya berbentuk sudut $90^{\circ}$ tidak berkorelasi, dan sebuah sudut yang lebih dari $90^{\circ}$ menujukkan jika variabel itu berkorelasi negatif. Nilai dari $p$ variabel dalam ke- $i$ vektor pengamatan $y_{i}$ (terkoreksi untuk rata-rata) adalah terkait dengan proyeksi tegak lurus dari titik $\left(x_{i 1}, x_{12}\right)$ pada $p$ vektor dari asal titik $\left(a_{j 1}, a_{j 2}\right)$ merepresentasikan variabel. Semakin jauh dari asal proyeksi jatuh pada panah, semakin besar nilai pengamatan pada variabel 
tersebut. Oleh karena itu vektor akan berorientasi pada pengamatan yang memiliki nilai yang lebih besar pada variabel yang sesuai (Rencher, 2002).

\section{METODOLOGI PENELITIAN}

\subsection{Jenis dan Sumber Data}

Data statistik perikanan merupakan data sekunder yang bersumber dari Direktorat Jenderal Perikanan Tangkap Dan Direktorat Jenderal Budidaya dan juga Badan Pusat Statistika Natuna 2018. Statistik perikanan dibedakan atas data perikanan tangkap dan perikanan budidaya. Perikanan tangkap diklasifikasikan atas penangkapan ikan di laut dan di perairan umum. Perikanan budidaya diklasifikasikan atas jenis budidaya yaitu budidaya laut, tambak, kolam, karamba, jaring apung, dan sawah. Pada penelitian ini akan fokus pada 3 permasalahan yang terdiri dari:

A. Laju PDRB terhadap Pengeluaran Kapita, dan Index Kedalaman Kemiskinan

B. PBB terhadap Jumlah Penduduk, Jumlah Usaha Mikro, Total Usaha,Jumah Pedagang, dan Jumlah Koperasi

C. Variabel independent yang terdiri dari Jumlah Rumah Tangga Perikanan (Marine Fisheries), Produksi (Production), Jumlah Rumah Tangga Perikanan Budidaya (Aquaculture Fishery Households), Perahu Tanpa Motor (Nonpowered Boat), Perahu Motor Tempel (Outboard Motorboat), dan Kapal Motor (Inboard Motorboat).

\subsection{Langkah-langkah analisis data}

Langkah-langkah analisis data yang dilakukan untuk mencapai tujuan penelitian dapat dilihat pada gambar 9 dibagian lampiran dan juga dapat diuraikan sebagai berikut:

Regresi komponen utama

1. Melakukan analisis komponen utama sebagai berikut:

a. Mencari nilai eigen dan vektor eigen dengan menggunakan matriks kovarian atau matriks korelasi dengan bantuan software $\mathrm{R}$

b. Menghitung skor komponen utama

c. Menentukan jumlah komponen utama yang akan digunakan

2. Melakukan regresi komponen utama dengan meregresikan antara skor komponen yang diperoleh dengan variabel terikat

3. Mengembalikan persamaan regresi ke bentuk variabel standar

4. Menghitung standar error untuk masingmasing koefisien regresi dan menguji koefisien regresi secara individu

5. Mengembalikan persamaan regresi ke bentuk variabel asli.

Secara teknis metode ini akan mereduksi data multivariat (banyak data) yang mengubah (mentransformasi) suatu matrik data awal atau asli menjadi satu suatu set kombinasi linier yang lebih sedikit akan tetapi menyerap sebagian besar jumlah variansi dari data awal (Rezzy Eko Caraka and Yasin 2017). Tujuan utama adalah menggunakan seminimal mungkin komponen utama namun menjelaskan sebanyak mungkin jumlah variansi data asli. Jumlah peubah $(p)$ dari data awal yang dapat diekstrak menjadi komponen utama (k) adalah sama banyak, dengan kata lain $p=k$, hal ini berkebalikan dengan tujuan utama. Komponen yang digunakan hanya yang memiliki proporsi besar, maka $k$ harus lebih kecil dibanding $p(k<p)$. Hal ini menjelaskan harus sedikit mungkin komponen yang dipertahankan namun cukup memberikan sebagian besar informasi yang terdapat dalam data asli.

\section{HASIL DAN PEMBAHASAN \\ 4.1 Statistika Deskriptif Potensi Perikanan}

Keadaan wilayah geografis yang sebagian besarnya merupakan laut menjadikan potensi perikanan Kabupaten Natuna memiliki potensi yang sangat besar untuk dikembangkan. Perikanan tangkap lebih mendominasi baik dari segi jumlah rumah tangga usaha maupun produksi dibanding perikanan budidaya. Jumlah rumah tangga perikanan tangkap laut di Natuna berjumlah 5.221 rumah tangga. Kondisi ini mengalami kenaikan dibanding tahun 2017. Seiring dengan itu, jumlah produksi perikanan laut juga meningkat yaitu dari $65.180,34$ ton menjadi $86.141,74$ ton pada 2017 atau naik 32 persen.

Produksi dari setiap kecamatannya terutama Kecamatan Bunguran Utara dan Midai yang naik hampir 2 (dua) kali lipat dibanding tahun sebelumnya. Hal ini sejalan juga dengan kenaikan jumlah rumah tangga perikanan tangkap yaitu di Bunguran Utara sebesar 28,7 persen dan Midai 10,2 persen. Namun, satu satunya kecamatan yang mengalami penurunan produksi yaitu Bunguran Tengah yaitu 12 persen dapat dilihat pada Gambar 1 (lampiran).

\subsection{Potensi Natuna}

Menurut Undang-Undang No 45 Tahun 2009 tentang perubahan atas Undang-undang No.31 Tahun 2004 tentang Perikanan, perikanan budi daya adalah semua kegiatan yang berhubungan dengan pengelolaan dan pemanfaatan sumber daya ikan dan lingkungannya mulai dari praproduksi, produksi, pengolahan sampai dengan pemasaran yang dilaksanakan dalam suatu sistem bisnis perikanan.

Lebih lanjut lagi disebutkan bahwa pembudidayaan ikan adalah kegiatan untuk memelihara, membesarkan, dan/atau membiakkan ikan serta memanen hasilnya dalam lingkungan yang terkontrol, termasuk kegiatan yang menggunakan kapal untuk memuat, mengangkut, menyimpan, mendinginkan, menangani, mengolah, dan/atau mengawetkannya. 
Sehingga, dapat dikatakan bahwa perikanan budi daya merupakan suatu subbagian kegiatan perikanan yang memproduksi sumber daya ikan dan lingkungannya, mulai dari pemeliharaan, pembesaran, dan pembiakkan serta pemanenan ikan di lingkungan yang masih terkontrol oleh pembudidaya dengan bantuan input yang ada. Terdapat beberapa faktor yang sangat menentukan keberhasilan kegiatan budi daya ikan yang dilaksanakan yaitu faktor independen dan faktor dependen. Faktor independen adalah faktor-faktor yang umumnya tidak dipengaruhi oleh faktor-faktor lain. Faktor-faktor tersebut adalah:

\section{Lingkungan}

Ciri-ciri fisik lingkungan (Kamargo and Simbolon 2018) yang penting bagi pengembangan budidaya perikanan sangat bergantung kepada ketersediaan dan kecocokan fisik dari areal

untuk pengembangan budidaya perikanan yaitu:

a. tersedianya lahan,

b. topografi dan elevasi lahan,

c. sifat-sifat tanah, teristimewa komposisi, tekstur dan kemampuan menahan air, sifat oseanografi perairan,

d. frekuensi, jumlah dan disfiibusi hujan,

e. mutu, kuantitas, ketersediaan dan aksesibilitas air,

f. kondisi cuaca, seperti suhu, laju penguapan, perubahan musim, frekuensi topan dan lamanya,

g. kualitas dan kuantitas populasi,

h. akses ke supply dan pasar.

\section{Faktor Manusia}

Faktor manusia meliputi sikap, adat istiadat dan gaya hidup dari warga, stabilitas dan kekuatan ekonomi serta politik dari pemerintah. Faktor-faktor ini beragam dan kompleks, contohnya:

a. Sikap dan keterampilan produsen relatif terhadap mengadopsi teknologi dan modal untuk ditanamkan dalam produksi,

b. Permintaan pasar, sikap konsumen, daya beli,

c. Kemauan dan kemampuan pemerintah melengkapi prasarana, kredit dan sebagainya, kemampuan Lembaga Pemerintah melengkapi sistem dukungan pelayanan bagi pengembangan budidaya perikanan antara lain pelatihan bagi profesional, penelitian guna mengembangkan teknologi baru, dan penyuluhan.

Sedangkan faktor dependen adalah faktor-faktor yang dipengaruhi oleh faktor-faktor lainnya. Faktor-faktor tersebut ialah wadah budi daya ikan, input hara, spesies ikan, dan teknologi. Wadah budi daya ikan seperti tambak, kolam, keramba, dan sebagainya sangat dipengaruhi oleh faktor lingkungan fisik dan manusia misalnya:

a. Kolam lebih cocok di daerah lahan pegunungan. b. Keramba jaring apung dikembangkan di perairan waduk dan laut.

Input hara berupa pupuk dan pakan tergantung kualitas dan kuantitasnya pada faktor lingkungan fisik, misalnya unsur ramuan pakan tidak dapat diproduksi dimana lingkungan fisik tidak cocok bagi produksinya. Spesies ikan yang dibudidayakan sangat tergantung dari faktor-faktor spesifik tiap spesies misalnya Tilapia tidak cocok dibudidayakan pada saat suhu rendah di bawah $200^{\circ} \mathrm{C}$.Teknologi yang menggunakan karamba jaring apung menuntut pemberian pakan yang intensif

\subsubsection{Laju PDRB terhadap Pengeluaran Kapita, Index Kedalaman Kemiskinan, dan Gini Rasio}

Pada tahap ini akan dianalisis mengenai laju PDRB pada Kabupaten Natuna terhadap pengeluaran kapita dan index kedalaman kemiskinan dan gini rasio. Angka pertumbuhan ekonomi (PDRB riil) Kabupaten Natuna tahun 2017 mencapai 5.68 persen, angka ini mengalami penurunan dari pertumbuhan 2016 yang sebesar 6.06 persen. Hal ini menunjukkan ekonomi Kabupaten Natuna sepanjang 2017 mengalami perlambatan. Pengeluaran rata-rata per kapita atau biaya yang dikeluarkan untuk konsumsi semua anggota rumah tangga selama sebulan baik yang berasal dari pembelian, pemberian maupun produksi sendiri dibagi dengan banyaknya anggota rumah tangga dalam rumah tangga tersebut memiliki vektor yang sangat jauh dengan index kedalaman kemiskinan dan ketimpangan pengeluaran penduduk Indonesia yang diukur oleh gini rasio.

Kedekatan antara variabel dapat dilihat pada Gambar 2. Pada biplot, variabel akan digambarkan sebagai garis berarah. Dua variabel yang memiliki nilai korelasi positif akan digambarkan sebagai dua buah garis dengan arah yang sama atau membentuk sudut sempit. Sementara itu, dua variabel yang memiliki nilai korelasi negatif akan digambarkan dalam bentuk dua garis dengan arah yang berlawanan atau membentuk sudut lebar (tumpul).

Sedangkan dua variabel yang tidak berkorelasi akan digambarkan dalam bentuk dua garis dengan sudut yang mendekati $90^{\circ}$ (siku-siku). Keragaman yang dapat diterangkan oleh biplot komponen Gambar 2 dimensi adalah sebesar 77,28\% yang berarti Gambar 2 mampu menerangkan 77,28\% dari total keragaman data yang sebenarnya. Hal ini menunjukkan bahwa interpretasi biplot komponen utama yang dihasilkan mampu menerangkan dengan baik hubungan antara laju PDRB pada Kabupaten Natuna terhadap pengeluaran kapita dan index kedalaman kemiskinan dan gini rasio di Natuna. 


\subsubsection{PBB Terhadap Jumlah Penduduk, Jumlah Usaha Mikro, Total Usaha,Jumah Pedagang, dan Jumlah Koperasi}

Pada tahap ini disajikan dendogram untuk melihat kedekatan antara masing-masing daerah di Natuna dengan melibatkan variabel Pajak Bumi Bangunan terhadap Jumlah Penduduk, Jumlah Usaha Mikro, Total Usaha, Jumlah Pedagang dan Jumlah Koperasi.

Berdasarkan Gambar 5 sumbu horizontal dendrogram mewakili jarak atau ketidaksamaan antar klaster. Sumbu vertical mewakili objek dan cluster. Dendrogram cukup mudah diinterpretasikan. Setiap gabungan atau fusi dari dua cluster diwakili pada grafik dengan pemisahan garis horizontal menjadi dua garis horizontal. Posisi horizontal perpecahan, ditunjukkan oleh bilah vertikal pendek, memberi perbedaan antara kedua kelompok. Ada dua cara untuk menafsirkan dendrogram: dalam hal kelompok skala besar atau dalam hal kesamaan di antara potongan individu. Untuk mengidentifikasi kelompok skala besar, dapat dimulai membaca dari atas ke bawah, menemukan titik cabang yang paling tinggi level dalam struktur.

Seterusnya, Gambar 5 dapat dilihat bahwa tahap pertama kekerabatan terdekat pada daerah Pulau Tiga dengan Serasan, Bunguran Batubi, Bunguran Timur Laut dan Bunguran Tengah. Seterusnya yang paling berbeda adalah bunguran utara. Selama tahun 2017, luas lahan yang dikenakan pajak adalah 255,78 km sedangkan luas bangunan sebesar $1,07 \mathrm{~km}^{2}$. Penerimaan Pajak Bumi dan Bangunan sebesar 256,8 juta rupiah. Kecamatan dengan penerimaan PBB terbesar adalah Kecamatan Bunguran Utara yaitu sebesar 18,28 persen. Jumlah koperasi terbanyak terdapat pada daerah Bunguran Timur dan perlu perhatian terhadap daerah Suak Midai, Bunguran Batubi, Subi, dan Bunguran Tengah.

Total usaha mempunyai jarak Euclidian terpanjang sehingga dapat disimpulkan bahwa setiap daerah di Natuna memiliki perbedaan yang signifikan terhadap banyaknya total usaha jika dibandingkan dengan jumlah penduduk. Hal ini akan berdampak pada jumlah koperasi, jumlah pedagang dan juga jumlah usaha mikro pada daerah tersebut. Keragaman yang dapat diterangkan oleh biplot komponen Gambar 3 dimensi adalah sebesar 82,17\% yang berarti Gambar 3 mampu menerangkan $82,17 \%$ dari total keragaman data yang sebenarnya.

\subsubsection{Jumlah Rumah Tangga Perikanan terhadap Produksi Jumlah Rumah Tangga Perikanan Budidaya, dan Fasilitas Perikanan}

Pada tahap ini kemudian dilakukan analisis menggunakan variabel Jumlah Rumah Tangga Perikanan (Marine Fisheries), Produksi (Production), Jumlah Rumah Tangga Perikanan Budidaya (Aquaculture Fishery Households), Perahu tanpa motor (nonpowered boat), Perahu motor tempel (outboard motorboat), dan kapal motor (inboard motorboat). Analisis biplot komponen utama dapat digunakan untuk mengetahui nilai keragaman variabel yang digunakan. Dari nilai keragaman variabel dapat diperoleh informasi untuk melihat apakah ada variabel yang hampir semua objek nilainya hampir sama atau sebaliknya ada yang besar dan ada juga yang kecil. Sehingga dapat digunakan sebagai strategi untuk menentukan variabel mana yang harus ditingkatkan performanya.

Variabel yang memiliki keragaman kecil akan digambarkan oleh vektor garis yang pendek. Sedangkan variabel yang memiliki keragaman besar akan digambarkan oleh vektor garis yang panjang. Berdasarkan Gambar 4 surface kendaraan tangkap ikan daerah Serasan memiliki potensi yang sangat banyak dibandingkan daerah lain dan terdapat gap pada daerah Burguran Timur Laut, Burguran Tengah dan Pulau Tiga dimana jumlah kendaraan tangkap ikan sedikit dibandingkan daerah lain. Berdasarkan Gambar 5 pada lampiran dapat digunakan untuk melihat kedekatan antar objek yang diamati. Objek-objek yang memiliki kemiripan karakteristik digambarkan sebagai titik yang saling berdekatan.

Selain melalui Gambar 6 kedekatan antar objek dapat diketahui dengan menghitung jarak Euclidian antara objek yang satu dengan yang lain. Semakin kecil nilai jarak Euclidian menunjukkan semakin dekat kedua objek tersebut. Dimensi fasilitas untuk menangkap ikan yang terdiri dari Perahu tanpa motor (nonpowered boat), Perahu motor tempel (outboard motorboat), dan kapal motor (inboard motorboat) memiliki garis vector yang sama setiap daerah di Natuna dan dapat diliihat bahwa garis vektor paling pendek adalah kapal motor (inboard motorboat) sehingga pemerintah daerah perlu membantu penggiat usaha tangkap ikan dimasing masing daerah dengan memperhatikan kapal motor (inboard motorboat).

Analisis biplot komponen utama dapat digunakan untuk mengetahui korelasi diantara variabel yang digunakan. Korelasi dapat diketahui dari besar sudut yang terbentuk antar vektor variabel. Jika sudut yang terbentuk dari kedua vektor variabel mendekati $0^{\circ}$ dan semakin sempit serta mempunyai arah yang sama atau nilai $\cos \theta$ yang terbentuk mendekati 1 maka variabel tersebut memiliki korelasi yang positif. Jika kedua vektor variabel berlawanan arah dan membentuk sudut yang lebar atau nilai $\cos \theta$ yang terbentuk mendekati 0 maka variabel tersebut korelasi yang negatif.

Sedangkan untuk variabel yang tidak berkorelasi digambarkan dengan dua garis membentuk sudut mendekati $90^{\circ}$. Untuk melihat korelasi antara variabel dapat dilihat pada corrplor di Gambar 7 bahwa terdapat hubungan yang kuat dan signifikan antara produksi dengan variabel fasilitas untuk menangkap.

Dari semua variabel dapat dilihat pengelompokan spasial pada gambar 8 . Untuk pemetaan potensi secara spasial dapat dikelompokan berdasarkan 4 dimensi 
Dimensi 1 : Midai, Serasan Timur, Bunguran Timur Laut, Serasan, Bunguran selatan

Dimensi 2: Bunguran Utara, Pulau Laut

Dimensi 3 : Subi, Bunguran Tengah, Pulau Tiga, Pulau Tiga Barat

\section{Dimensi 4: Bunguran Timur}

\subsection{Karakteristik Sosial Rumah Tangga Usaha Budi Daya Maritim}

Karakteristik sosial rumah tangga usaha budi daya dapat dijelaskan pada butir berikut:

1. Banyak anggota rumah tangga (ART) atau tanggungan

Banyak anggota rumah tangga (ART) merupakan banyaknya orang yang berada dalam manajemen rumah tangga termasuk kepala keluarga. Hal ini akan berpengaruh terhadap pola produksi dan konsumsi petani serta mengakibatkan perbedaan produksi dan pendapatan (Sahara et al., 2004). Banyaknya ART merupakan salah satu sumber daya manusia yang dimiliki, terutama yang berusia produktif dan ikut membantu dalam usahanya. Banyaknya ART juga dapat menjadi beban hidup bagi keluarganya apabila tidak aktif bekerja (Syafruddin, 2003 dalam Zulkarnain, 2011).

Banyaknya ART akan mendorong petani untuk melakukan banyak kegiatan atau aktivitas terutama dalam upaya mencari dan menambah pendapatan keluarga (Ginting, 2002 dalam Sirait, 2009). Hal ini dipertegas dengan pernyataan dari Soekartawi (1990) yang mengungkapkan bahwa semakin banyak ART akan sangat memengaruhi keputusan petani dalam berusahatani. Kegagalan petani dalam berusahatani akan sangat berpengaruh terhadap pemenuhan kebutuhan keluarga. Banyak ART yang besar seharusnya memberikan dorongan yang kuat untuk berusahatani intensif dengan menerapkan teknologi baru, sehingga akan meningkatkan usahatani (Sirait, 2009).

\section{Jenis kelamin pembudidaya}

Jenis kelamin dapat memengaruhi tingkat produktivitas seseorang. Secara universal, tingkat produktivitas laki-laki lebih tinggi daripada perempuan. Hal tersebut dipengaruhi oleh faktorfaktor yang dimiliki oleh perempuan seperti: fisik yang kurang kuat, dalam bekerja cenderung menggunakan perasaan, atau faktor biologis seperti harus cuti ketika haid atau sedang melahirkan (Amron dan Taufik, 2003).

Perempuan di masyarakat terkenal lemah, cantik, emosional, dan keibuan. Adapun laki-laki dikenal kuat, jantan, rasional, dan perkasa. Perbedaan ciri-ciri dan sifat-sifat ini dapat terjadi dari waktu ke waktu, dari satu tempat ke tempat lain. Perempuan memiliki sikap kehati-hatian yang sangat tinggi, cenderung menghindari resiko, dan lebih teliti dibandingkan laki- laki. Sisi inilah yang membuat wanita tidak terburuburu dalam mengambil keputusan.

\section{Umur pembudidaya}

Semakin muda umur seseorang, semakin tinggi juga semangat untuk ingin tahu apa yang belum mereka ketahui, sehingga dengan demikian mereka berusaha untuk lebih cepat melakukan anjuran dari kegiatan penyuluhan (Ginting, 2002 dalam Sirait, 2009). Soeharjo dan Patong (1973:51) mengatakan bahwa umur seseorang akan memengaruhi kemampuan fisik bekerja dan cara berpikir. Orang yang lebih muda biasanya cenderung lebih agresif dan lebih dinamis dalam berusaha bila dibandingkan dengan yang lebih tua. Di samping itu, umur juga memengaruhi seseorang dalam mengelola usahanya. Kartasapoetra (1994) mengungkapkan bahwa petani yang berusia lanjut sekitar 50 tahun keatas biasanya fanatik terhadap tradisi dan sulit untuk diberikan pengertian yang dapat mengubah cara berpikir, cara kerja, dan cara hidupnya. Mereka lebih bersifat apatis terhadap adanya teknologi baru.

Umur juga dapat digunakan sebagai pendekatan untuk pengalaman. Pengalaman merupakan suatu pengetahuan yang diperoleh melalui rutinitas kegiatannya sehari-hari atau peristiwa yang pernah dialaminya.

Pada penelitiannya (Anwar and Utpalasari 2017) menggunakan analisis regresi linear sederhana untuk mengetahui pengaruh jumlah anggota, umur pembudidaya, tingkat pendidikan, dan luas lahan yang digunakan terhadap jumlah produksi ikan didapatkan hanya umur yang berpengaruh nyata terhadap jumlah produksi ikan pada taraf 5\%, sementara yang lain tidak berpengaruh nyata.

Pengalaman yang dimiliki merupakan salah satu faktor yang dapat membantu memecahkan masalah yang dihadapi dalam usahanya. Pembudidaya dengan umur yang lebih tua akan memiliki pengalaman yang lebih banyak tentang usaha budi daya dibandingkan pembudidaya yang lebih muda. Semakin lama pengalaman yang dimiliki oleh pembudidaya maka pembudidaya tersebut akan cenderung memiliki tingkat keterampilan yang tinggi sehingga akan mendukung keberhasilan dalam usahanya.

\section{Tingkat pendidikan pembudidaya}

Slamet (2003) menyatakan bahwa perilaku petani dipengaruhi oleh pengetahuan, kecakapan, dan sikap mental petani itu sendiri. Digiatkannya penyuluhan pertanian diharapkan akan terjadi perubahanperubahan, terutama pada perilaku dan bentuk-bentuk kegiatannya seiring dengan terjadinya perubahan cara berpikir, cara kerja, cara hidup, pengetahuan, dan sikap mental yang lebih terarah dan lebih menguntungkan, baik bagi dirinya beserta keluarganya maupun lingkungannya. Menurut Ginting (2002), pendidikan merupakan sarana belajar yang selanjutnya akan menanamkan sikap yang menguntungkan menuju penggunaan praktik pertanian yang lebih modern. 
Mereka yang berpendidikan tinggi relatif lebih cepat dalam melakukan anjuran penyuluh. Tingkat pendidikan yang rendah umumnya kurang menyenangi inovasi sehingga sikap mental untuk menambah ilmu pengetahuan khususnya ilmu pertanian kurang (Sirait, 2009). Pendidikan dapat berasal dari pendidikan formal dan nonformal. Pendidikan formal merupakan suatu usaha mengadakan perubahan perilaku berdasarkan ilmu dan pengetahuan yang diperoleh masyarakat dari sekolah dasar sampai perguruan tinggi. Sedangkan pendidikan nonformal biasanya diperoleh melalui pendidikan luar di sekolah, misalnya penyuluhan, kursus, dan pelatihan.

Faktor pendidikan akan memengaruhi cara berpikir pembudidaya dalam mengelola usaha budi dayanya. Pendidikan umumnya membuat seseorang berpikir ilmiah sehingga mampu untuk membuat keputusan dari berbagai alternatif dalam mengelola usahanya. Pembudidaya dengan tingkat pendidikan yang lebih tinggi diduga memiliki kemampuan yang lebih baik dalam memahami dan menerapkan teknologi produktif sehingga penggunaan inputnya menjadi lebih efisien dan produktivitasnya lebih tinggi. Selain itu, pendidikan akan memberikan atau menambah kemampuan dari pembudidaya dalam mengambil keputusan dan mengatasi masalahmasalah yang terjadi.

\section{Sumber modal utama}

Wirausaha umumnya mempunyai tenaga, keinginan untuk berinovatif, kemauan menerima tanggung jawab pribadi mewujudkan suatu peristiwa dengan cara yang mereka pilih, dan keinginan untuk berprestasi yang sangat tinggi (Purwanti 2012). Selain itu, sikap optimis dan kepercayaan terhadap masa depan. Meskipun imbalan dalam kewirausahaan menggiurkan, tapi ada juga biaya yang berhubungan dengan kepemilikan bisnis tersebut. Memulai dan mengoperasikan bisnisnya sendiri, memerlukan kerja keras, menyita banyak waktu dan membutuhkan kekuatan emosi. Wirausaha mengalami tekanan pribadi yang tidak menyenangkan seperti kebutuhan untuk menginvestasikan lebih banyak waktu dan tenaganya . Banyak wirausaha menggambarkan kariernya menyenangkan, tetapi sangat menyita segalanya. Kemungkinan gagal dalam bisnis adalah ancaman yang selalu ada bagi wirausaha, tidak ada jaminan kesuksesan, tantangan yang berupa kerja keras, tekanan emosional, dan resiko meminta tingkat komitmen dan pengorbanan .

Salah satu faktor produksi yang penting yaitu modal. Semua kegiatan usaha dalam mendapatkan hasil diperlukan sejumlah modal untuk membiayai aktivitas usahanya. Karena tanpa adanya modal, aktivitas tersebut tidak dapat berjalan sesuai dengan apa yang diinginkan. Modal ada yang bersumber dari modal sendiri dan bukan modal sendiri atau modal pinjaman. Modal sendiri merupakan modal yang berasal dari perusahaan itu sendiri (cadangan atau laba), atau berasal dari pengambil bagian, peserta, atau pemilik (modal saham, modal peserta, dll). Kemudian, menurut pedoman pencacah Survei Rumah Tangga Usaha Budidaya Ikan 2014, modal sendiri adalah modal yang berasal bukan dari pinjaman, tetapi milik sendiri (simpanan sendiri, dsb).

Sedangkan modal pinjaman merupakan modal yang diperoleh berasal dari pinjaman, seperti pinjaman bank, koperasi, pegadaian, perorangan, dan sebagainya. Modal sendiri adalah modal yang menanggung resiko atau ekuitas, sehingga apabila dalam suatu tahun usaha menderita kerugian maka yang menanggung kerugian tersebut adalah pembudidaya sendiri. Namun, dengan menggunakan modal sendiri, pembudidaya tidak menanggung beban harus mengembalikan sejumlah modal kepada pihak lain, sehingga diduga pembudidaya kurang termotivasi untuk meningkatkan usahanya yang dapat berpengaruh pula terhadap produktivitas usahanya. Sedangkan ketika menggunakan modal pinjaman, pembudidaya mempunyai tanggungan untuk mengembalikan sejumlah modal yang dipinjam tersebut kepada pihak lain, sehingga motivasi pembudidaya dalam berusaha akan semakin tinggi.

Pemilik usaha harus memahami kondisi Pasar. Pasar sebagai kelompok pembeli atau pihak yang menjadi sasaran dalam penjualan, dapat pula mempengaruhi kegiatan penjualan (Sartika 2018). Adapun faktor kondisi pasar yang perlu diperhatikan adalah jenis pasar, kelompok pembeli, daya belinya, frekuensi pembeliannya, dan keinginan serta kebutuhannya dan juga besar biasanya masalah penjualan ini ditangani oleh bagian tersendiri. Yang dipegang oleh orang-orang tertentu atau ahli dalm bidang penjualan, sedangkan dalam perusahaan kecil biasanya masalah penjualan masih ditangani oleh orang yang juga melaksanakan fungsi-fungsi lainnya.

\subsection{Peran LPDB}

Setelah dianalisis daerah yang paling potensial adalah yang terkelompok pada Dimensi 1 yaitu Midai, Serasan Timur, Bunguran Timur Laut, Serasan, Bunguran selatan. Pada analisis sebelumnya yaitu laju PDRB terhadap Pengeluaran Kapita, Index Kedalaman Kemiskinan, Gini Rasio didapatkan hasil yang signifikan. LPDB-KUMKM apabila hendak fokus terhadap menurunkan tingkat kemisikinan dapat fokus terhadap daerah Serasan yang memiliki pendapatan PBB terkecil. Untuk meningkatkan potensi Koperasi, Total Usaha, Jumlah Pedagang dan Jumlah Usaha Mikro perlu perhatian khusus pada daerah Suak Midai, Banguran Batubi. Darerah yang dapat dikategorikan paling siap dan cukup matang untuk dikembangkan lagi adalah Bunguran Timur dimana memiliki pedagang terbanyak yaitu berjumlah 216, 24 koperasi dan 450 total usaha. 


\section{KESIMPULAN}

Pemanfaatan sumber daya laut yang melimpah secara optimal merupakan modal strategis untuk mewujudkan Indonesia sebagai negara kepulauan yang berorientasi maritim. Pembangunan Sumber Daya Manusia (SDM) juga berperan penting dalam keberhasilan pembangunan. SDM merupakan pelaku sekaligus pemanfaat pembangunan. Peningkatan keterampilan SDM berkaitan erat dengan peningkatan kemampuan individu untuk mandiri, mengenali potensi diri, kendala yang dihadapi berikut solusinya.

Sektor kelautan dan perikanan merupakan dua sektor yang berhubungan langsung dengan desa maritim. Melalui peningkatan mutu SDM, terutama penduduk di desa Maritim, diharapkan dapat mengelola pemanfaatan laut sebagai aset pembangunan ekonomi berkelanjutan di masa depan.

Berdasarkan analisis yang didapatkan telah terbentuk daerah yang memiliki kekerabatan yang sama yaitu:

Dimensi 1 : Midai, Serasan Timur, Bunguran Timur Laut, Serasan, Bunguran selatan

Dimensi 2 : Bunguran Utara, Pulau Laut

Dimensi 3 : Subi, Bunguran Tengah, Pulau Tiga, Pulau Tiga Barat

Dimensi 4 : Bunguran Timur

LPDB sebagai wadah untuk mengembangkan potensi bisnis di daerah terpencil dan potensial, perlu melakukan pengelompokan provinsi lainnya yang dapat di approach dan dikembangkan dalam waktu yang cepat dan tepat dan berbasis ekonomi kerakyatan.

Pembangunan berpusat pada rakyat adalah proses dimana anggota-anggota suatu masyarakat meningkatkan kapasitas perorangan dan institusional mereka untuk memobilisasi dan mengelola sumber daya untuk menghasilkan perbaikan-perbaikan yang berkelanjutan dan merata dalam kualitas hidup sesuai dengan aspirasi mereka sendiri. Definisi tersebut mencakup asas keadilan, berkelanjutan, dan ketercakupan. Ekonomi kerakyatan adalah sistem ekonomi yang berbasis pada kekuatan ekonomi rakyat, dimana ekonomi rakyat sendiri adalah kegiatan ekonomi yang dilakukan oleh rakyat kebanyakan yang secara swadaya mengelola sumber daya ekonomi apa saja yang dapat diusahakan. Landasan hukum ekonomi kerakyatan dijelaskan di dalam Undang-Undang Republik Indonesia No. 25 Tahun 2000 tentang Program Pembangunan Nasional. Ekonomi kerakyatan dinilai mampu menjadi penopang utama pertumbuhan ekonomi nasional.

Rusli (2016) menyatakan bahwa konsep pengembangan wilayah pesisir dapat dikembangkan oleh masyarakat dengan apa yang mereka miliki, guna meningkatkan kualitas hidupnya. Peningkatan kualitas manusia ini, harus diartikan sebagai motivasi untuk menyatukan secara harmonis antara sumber daya alam, manusia, dan teknologi, dengan mempertimbangkan daya tampung lingkungan itu.
SIlas (1993) menyatakan bahwa konsep pengembangan ruang permukiman produktif merupakan pendekatan integrasi dari rumah, dengan peluang menggalang berbagai sumber daya alam, manusia, dan buatan untuk dapat meningkatkan produktivitas masyarakat.

\section{IMPLIKASI DAN KETERBATASAN}

Segala aktivitas yang di dalamnya dapat menciptakan dan menambah pendapatan penduduk juga perlu kombinasi dan koordinasi material dan kekuatan (input, faktor, sumber daya, atau jasa produksi). Untuk mencerdaskan masyarakat maritim untuk memproduksi ikan yang baik perlu dua aspek penting:

a) Komposisi faktor produksi yang digunakan untuk menciptakan tingkat produksi yang tinggi

b) Komposisi faktor poduksi yang meminimumkan biaya produksi untuk mencapai satu tingkat produksi tertentu.

Pada permasalahan lain juga perlu menimbangkan faktor produksi terdiri atas alam (natural resources), tenaga kerja (labor), modal (capital), dan keahlian (skill) atau sumber daya pengusaha (enterpreneurship) dan juga faktor masyarakat maritim yang meliputi sikap, adat istiadat dan gaya hidup dari warga, stabilitas dan kekuatan ekonomi serta politik dari pemerintah. Lebih spesifik pada Sikap dan keterampilan produsen relatif terhadap mengadopsi teknologi dan modal untuk ditanamkan dalam produksi, permintaan pasar, sikap konsumen, daya beli, kemauan dan kemampuan pemerintah melengkapi prasarana, kredit.

\section{UCAPAN TERIMA KASIH}

Peneliti mengucapkan terima kasih kepada Kementerian Koordinator Bidang Kemaritiman Republik Indonesia yang telah menyelenggarakan kegiatan Ekspedisi Nusantara Jaya (ENJ). Terkhusus Dr. Ir. Safri Burhanuddin, DEA Deputi IV Bidang Koordinasi SDM, IPTEK dan Budaya Maritim.

Kegiatan ini tidak akan berhasil tanpa bantuan dari Pemerintah Daerah Midai, Natuna. Peneliti mengucapkan terima kasih kepada tim ENJ Natuna yang terlibat Aryo, Solihin, Zulham, Vita, Agi, Wicak, Alwi, Yuni, Yudi, Fuad, Ine, Rahmat, Bagus, Mulyadi, M.Ridwan, Qistina, Bagus, Atarik, Akbar, Fatwa Arief. 


\section{DAFTAR PUSTAKA}

Anwar, Syaeful, and Rih Laksmi Utpalasari. 2017. "Analisa Produksi Budidaya Ikan Konsumsi Kelompok Budidaya Ikan (POKDAKAN) Kecamatan Gandus Kota Palembang." Jurnal Ilmu-ilmu Perikanan dan Budidaya Perairan 12(2): 17-23.

Badan Pusat Statistik. 2015. KAJIAN DESA MARITIM 2015. Jakarta.

\section{_- 2018. BPS Kabupaten Natuna Dalam Angka} 2018. NATUNA.

Beh, Eric J. 2012. "Biplots in Practice.” Journal of the Royal Statistical Society: Series A (Statistics in Society).

BPS. 2015. "Hasil Sensus Pertanian 2013 (Angka Tetap).” In Berita Resmi Statistik, , 1-13.

Bradu, Dan, and K. Ruben Gabriel. 1978. "The Biplot as a Diagnostic Tool for Models of Two- Way Tables." Technometrics 20(1): 47-68.

Caraka, R.E., and M. Tahmid. 2019. Statistika Klimatologi. 1st ed. Yogyakarta: Mobius Graha Ilmu.

Caraka, R.E., and Hasbi Yasin. 2018. Spatial Data Panel. 1st ed. Wade Group. http://rezzyekocaraka.com/book.

Caraka, Rezzy Eko, and Hasbi Yasin. 2017. Geographically Weighted Regression (GWR) Sebuah Pendekatan Regresi Geografis. 1st ed. Yogyakarta: MOBIUS GRAHA ILMU. www.rezzyekocaraka.com/book.

Departemen Koperasi Indonesia. 2008. UndangUndang Nomor 20 Tahun 2008. Jakarta.

Firdamansyah, Agung. 2017. "DYNAMIC SYSTEM MODEL FOR IMPROVED PERFORMANCE OF SMALL MEDIUM ENTERPRISE THROUGH THE USE OF E-COMMERCE (CASE STUDY: CRAFT BUSINESS IN LAMONGAN)." ITS.

Gower, John, Sugnet Lubbe, and Niël le Roux. 2011. "Principal Component Analysis Biplots." In Understanding Biplots,

Greenacre, Michael. 2009. SSRN The Standard Biplot.
Kamargo, Gogo, and Domu Simbolon. 2018. "Strategi Pengelolaan Perikanan Tangkap Di Kawasan Konservasi Perairan Daerah (KKPD) Lingga Di Kabupaten Lingga." ALBACORE 2(3).

LPDB. 2017. LAPORAN AKUNTABILITAS KINERJA PEMERINTAH TAHUN 2017. Jakarta.

Pieter M, Kroonenberg. 2017. "Biplot Analysis.” Crop Science.

Pigawati, Bitta. 2005. "Identifikasi Potensi Dan Pemetaan Sumberdaya Pesisir Pulau-Pulau Kecil Dan Laut Kabupaten Natuna - Provinsi Kepulauan Riau." Ilmu Kelautan.

Purwanti, Endang. 2012. "Pengaruh Karakteristik Wirausaha, Modal Usaha, Strategi Pemasaran Terhadap Perkembangan Umkm Di Desa Dayaan Dan Kalilondo Salatiga." Jurnal Ilmiah Among Makarti 5(9): 14-28.

Rusli. 2016. "INTEGRASI RUANG PERMUKIMAN NELAYAN DENGAN EKOWISATA PESISIR DI DONGGALA SULAWESI TENGAH." ITS.

Sartika, Dewi. 2018. "Pengaruh Modal Terhadap Omset Pada Pelaku UMKM Di Seluruh Kecamatan Pekanbaru." Kompetif 4(2).

SIlas, J. 1993. Perumahan: Hunian Dan Fungsi Lebihnya Dari Aspek Sumberdaya Dan Eksistensinya.

Streiner, D. L. 1993. "An Introduction to Multivariate Statistics." Canadian Journal of Psychiatry 38(1): 9-13.

Subagyo, Agus et al. 2017. "KESIAPAN DAERAH DALAM MEWUJUDKAN VISI INDONESIA POROS MARITIM DUNIA." Poros Maritim Dunia (April 2015).

Triyono., and Toni. Romadona. 2018. "Penentuan Produk Unggulan Perikanan Dan Pengembangannya Di Pulau Terdepan Indonesia (Kasus Di Kabupaten Natuna)." TECHNO-FISH 2(2). 


\section{LAMPIRAN}

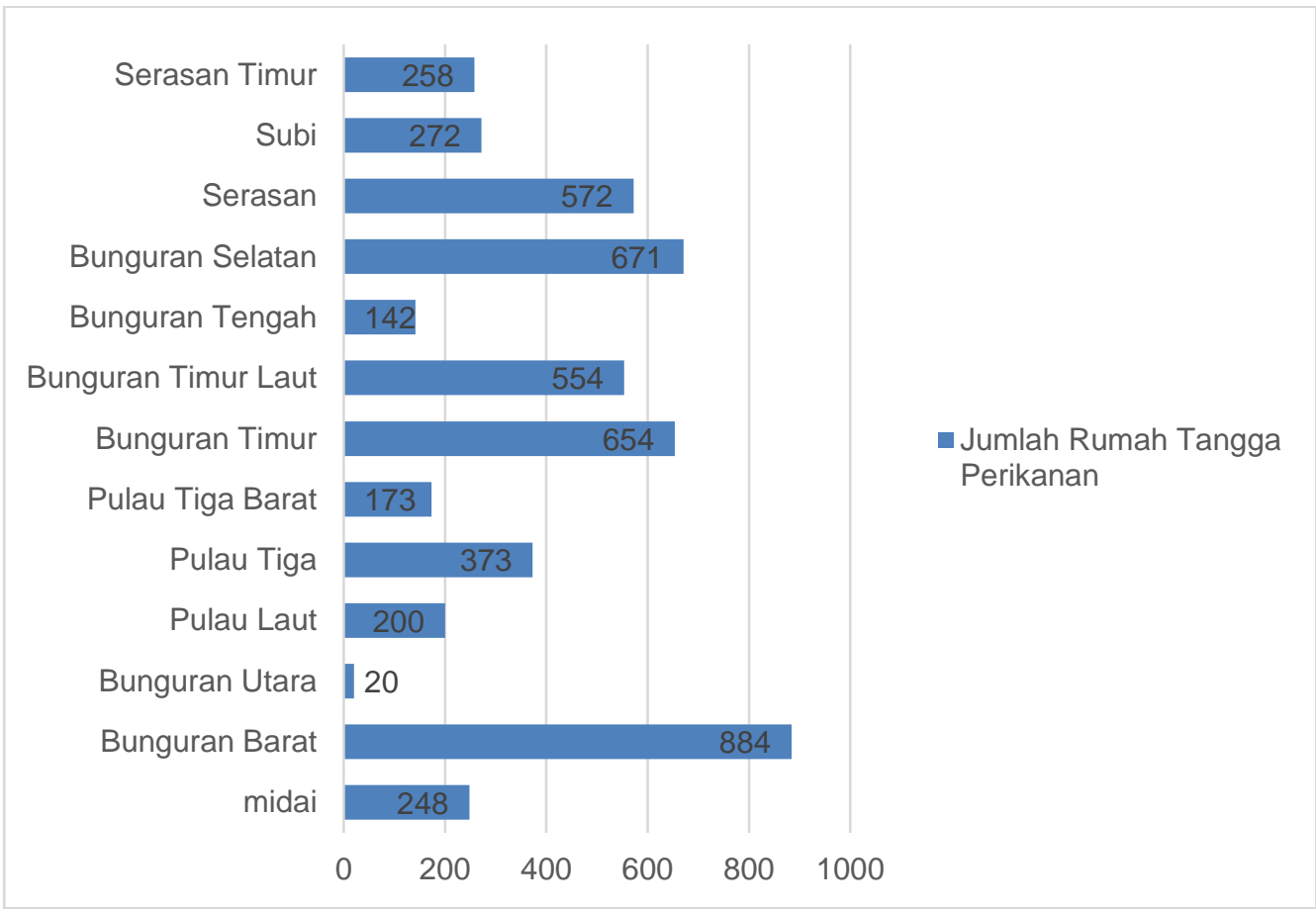

Gambar 1. Jumlah Rumah Tangga Perikanan

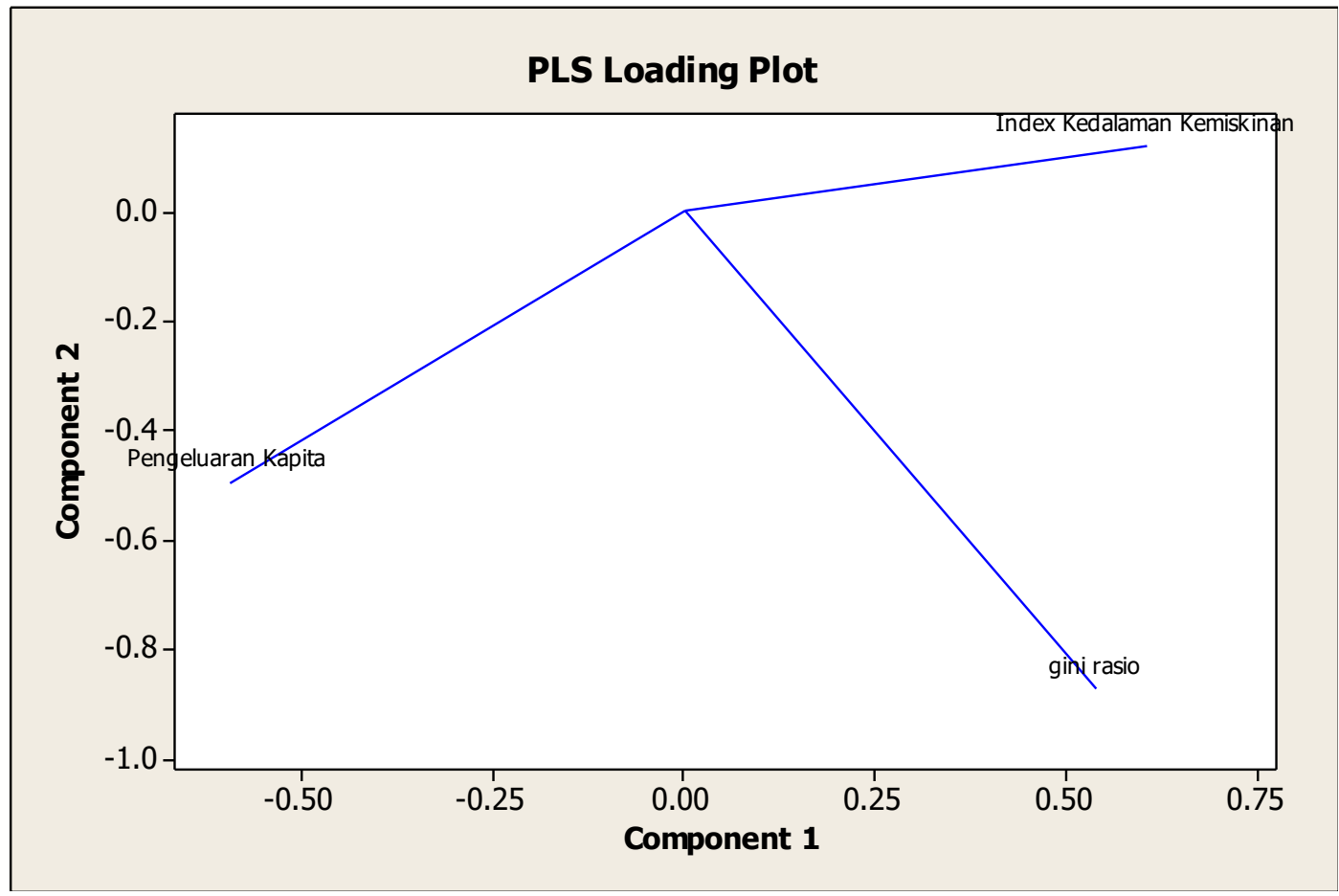

Gambar 2. Plot Variabel PCA Permasalahan 1 


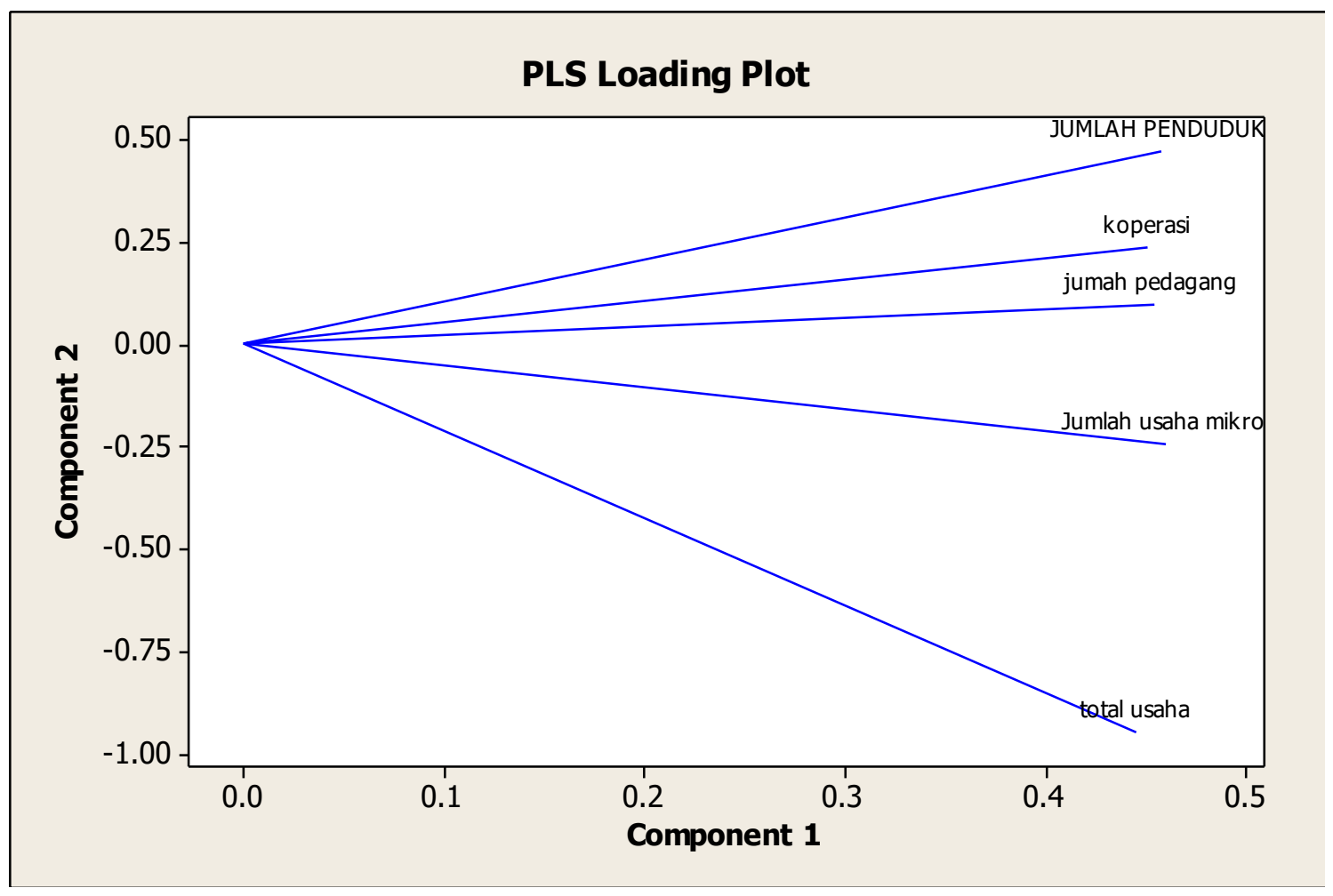

Gambar 3. Plot Variabel PCA Permasalahan 2

\section{Chart Surface Kendaraan Tangkap Ikan}

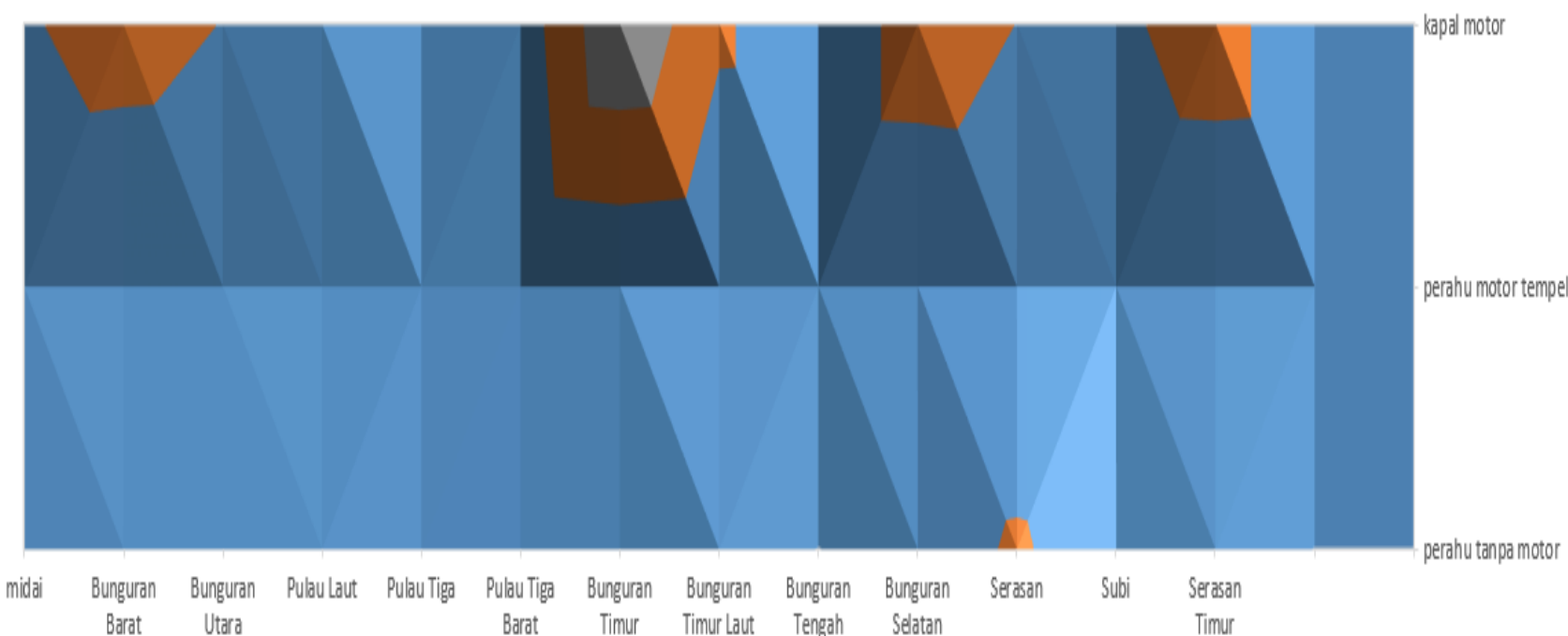

\section{$\| 0-200 \backsim 200-400 \backsim 400-600$}




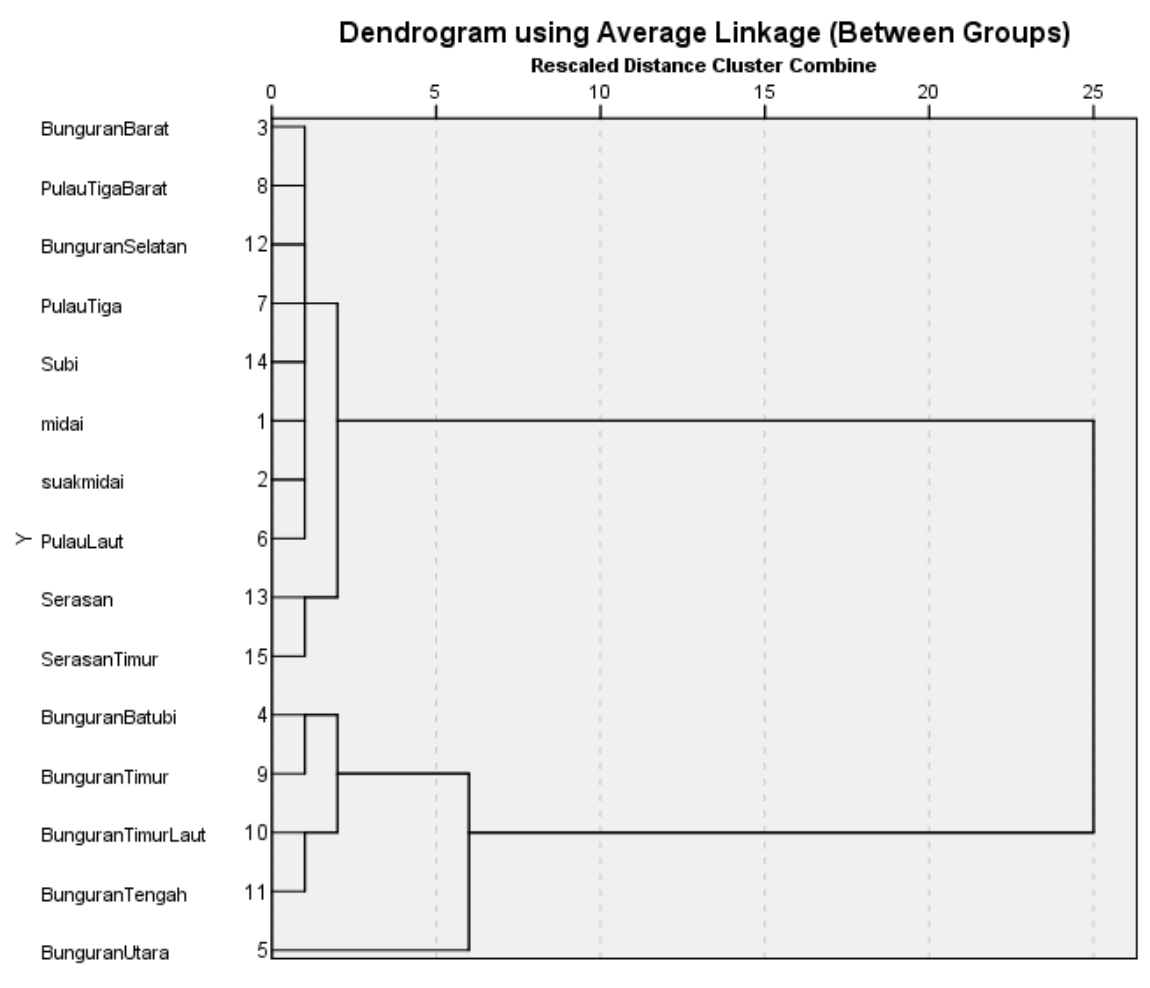

Gambar 5. Dendogram

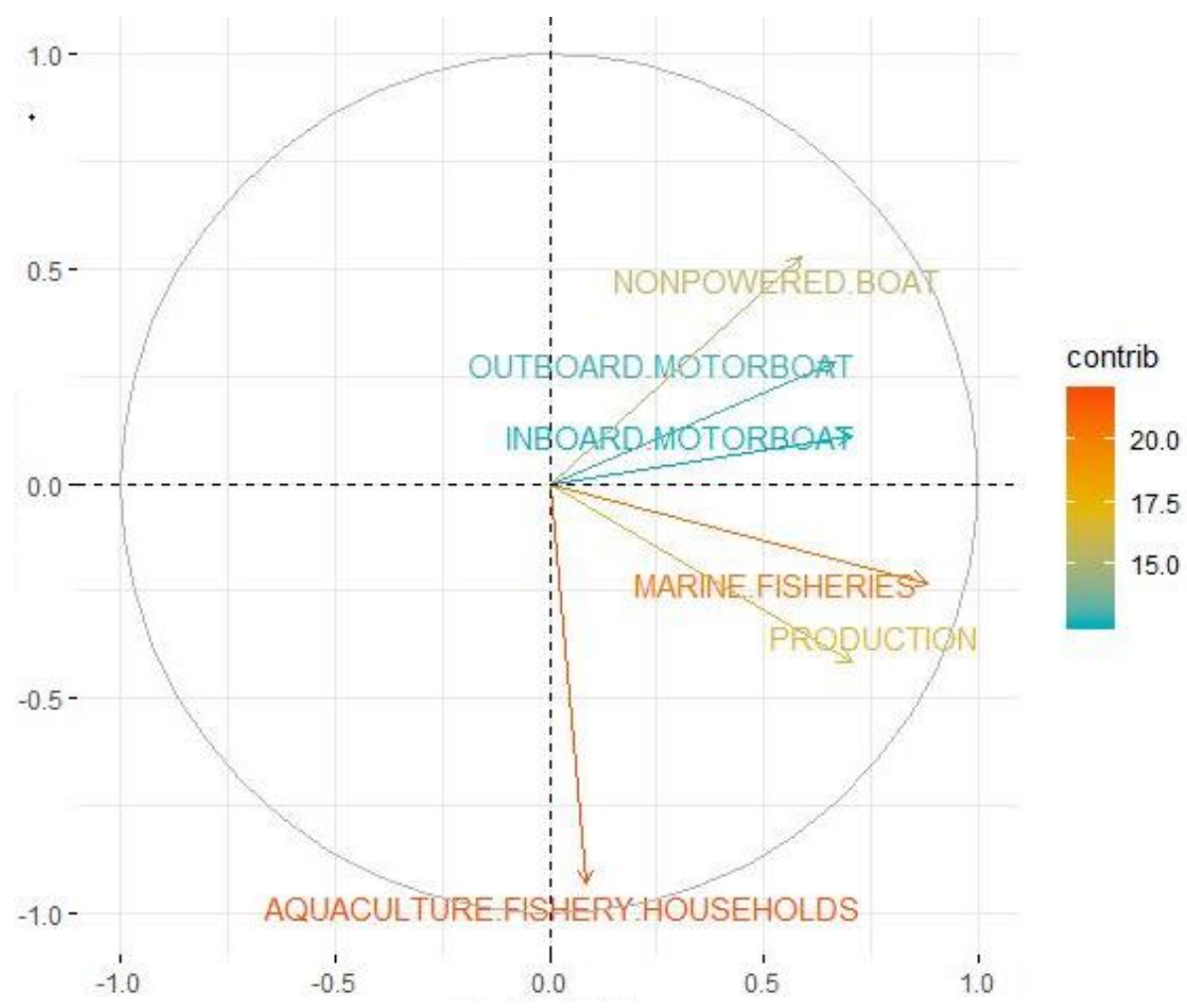

Gambar 6. Plot Variabel PCA 


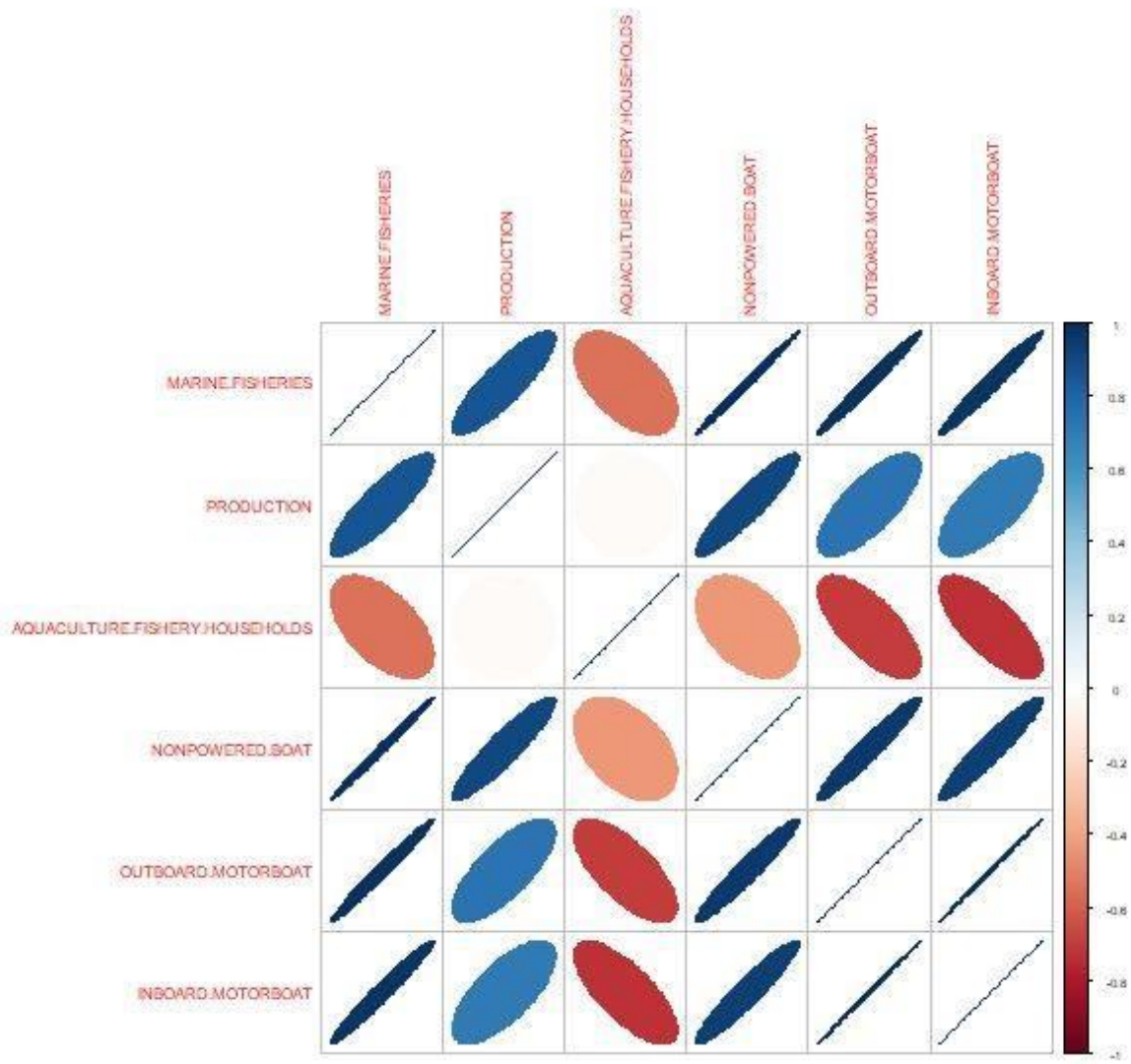

Gambar 7. Korelasi Plot

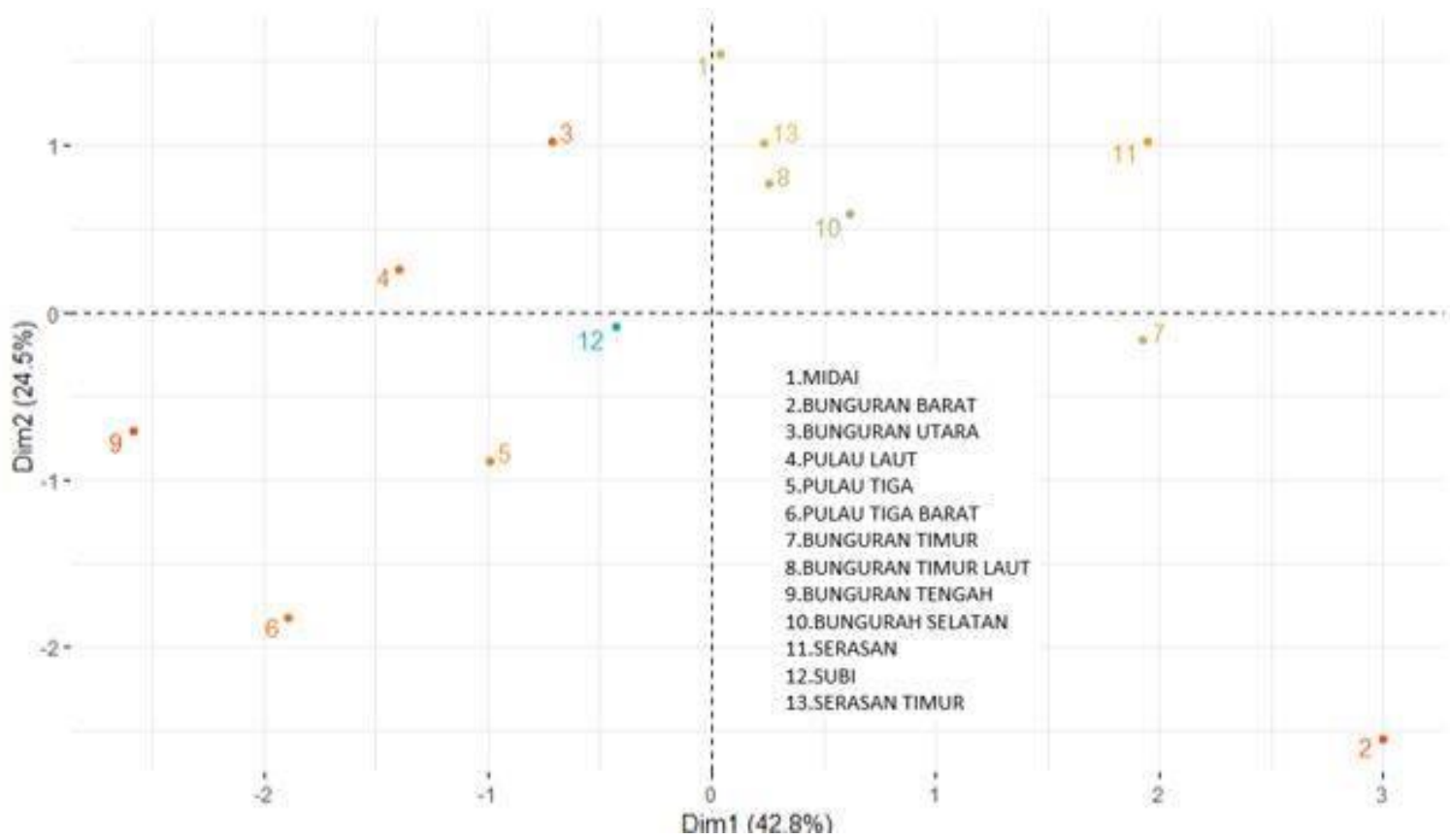

Gambar 8. Spasial Potensi 

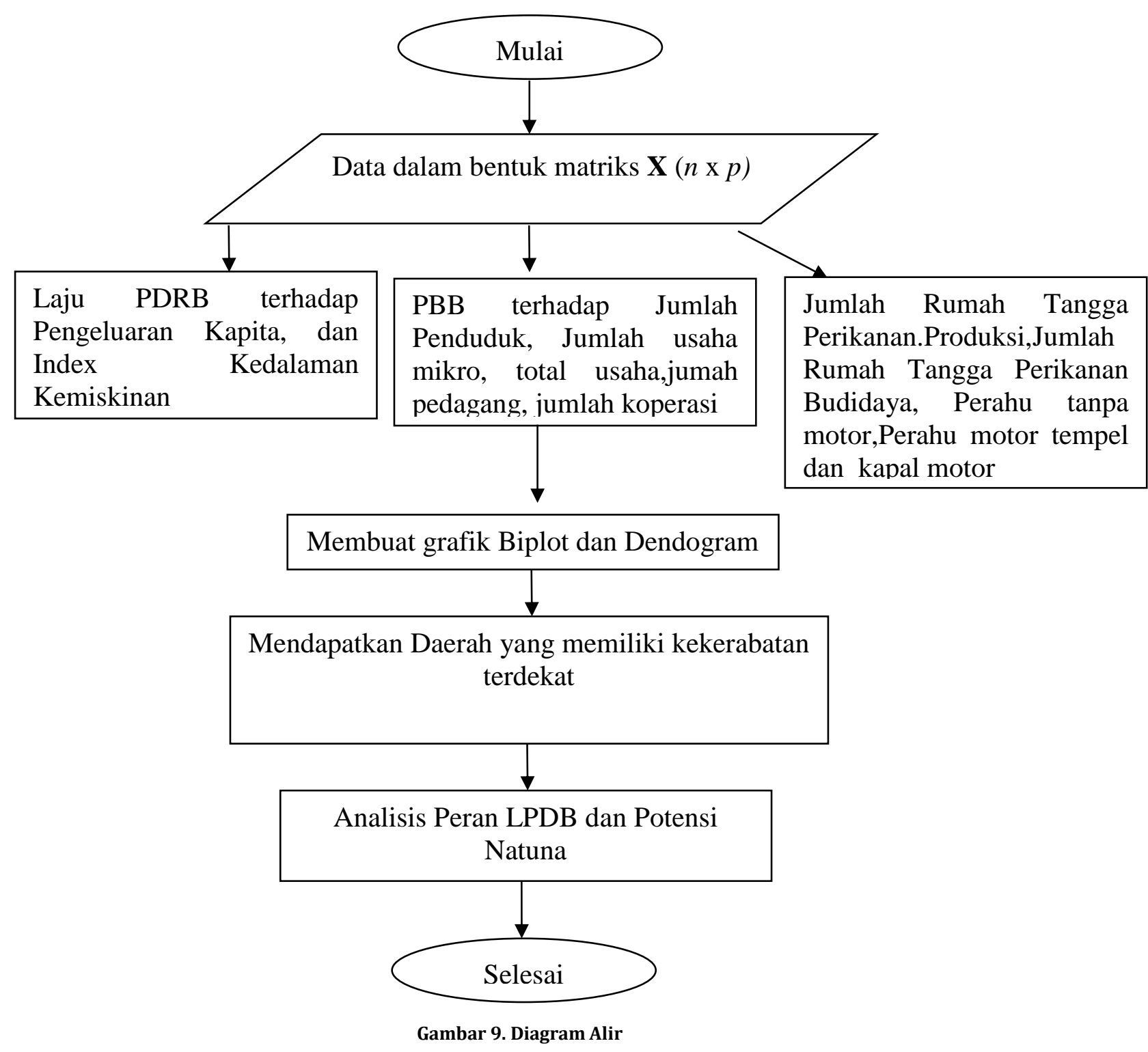